\title{
Transduction Methods for Cytosolic Delivery of Proteins and Bioconjugates into Living Cells
}

Manuela Chiper ${ }^{a, b}$, Karen Niederreither ${ }^{c}$, Guy Zuber ${ }^{a}$

Dr. Manuela Chiper

${ }^{a}$ Molecular and Pharmaceutical Engineering of Biologics, CNRS - Université de Strasbourg UMR 7242, Boulevard Sebastien Brant, 67412 Illkirch, France

${ }^{\mathrm{b}}$ Faculté de Pharmacie - Université de Strasbourg, 74 Route du Rhin, F-67400 Illkirch, France

Dr. Karen Niederreither

${ }^{\mathrm{c}}$ Developmental Biology and Stem Cells Department, Institute of Genetics and Molecular and Cellular Biology (IGBMC), Illkirch, France, CNRS UMR 7104, INSERM U 964, Faculté de Chirurgie Dentaire, Université de Strasbourg, Strasbourg, France

Dr. Guy Zuber

${ }^{a}$ Molecular and Pharmaceutical Engineering of Biologics, CNRS - Université de Strasbourg UMR 7242, Boulevard Sebastien Brant, 67412 Illkirch, France

E-mail: zuber@unistra.fr

Keywords: cytosolic delivery, protein carriers, intracellular delivery, protein transport, transduction

\section{Abstract}

The human organism and its constituting cells rely on interplay between multiple proteins exerting specific functions. Progress in molecular biotechnologies has facilitated the production of recombinant proteins. When administrated to patients, recombinant proteins can provide important healthcare benefits. To date, most therapeutic proteins must act from the extracellular environment, with their targets being secreted modulators or extracellular receptors. This is because proteins cannot passively diffuse across the plasma membrane into the cytosol. To expand the scope of action of proteins for cytosolic targets (representing more than $40 \%$ of the genome) effective methods assisting protein cytosolic entry are being developed. To date, direct protein delivery was extremely tedious and inefficient in cultured 
To link to this article (1) Chiper, M.; Niederreither, K.; Zuber, G. Transduction Methods for Cytosolic Delivery of Proteins and Bioconjugates Into Living Cells. Adv. Healthcare Mater. 2018, 7, e1701040.

Doi : 10.1002/adhm.201701040

cells, even more so in animal models of pathology. Novel techniques are changing this limitation, as recently developed in vitro methods can robustly convey large amount of proteins into cell cultures. Moreover, advances in protein formulation or protein conjugates are slowly, but surely demonstrating efficiency for targeted cytosolic entry of functional protein in vivo in tumor xenograft models. In this review, various methods and recently developed techniques for protein transport into cells are summarized. They are put into perspective to address the challenges encountered during delivery.

\section{Introduction}

Proteins are involved in maintaining cell and organ structure, along with regulating a multitude of physiological functions. Recent resolution of the molecular details of the proteome has provided a global view of the human genome, allowing both quantification and localization of protein levels in various tissues, even to a single cell level. ${ }^{[1]}$ The maximum number of protein-encoding genes is less than 20,344, and analysis of mRNA transcripts in 32 different human tissues showed that $44 \%$ of the total genetic pool $(8,874$ genes $)$ is expressed in all tissues. Of this, 1,832 genes (9\%) were not detected in any tissues and 2,696 genes $(13 \%)$ were detected in fewer than 32 tissues. Important tissue-specific variations in protein expression levels are observed for 6,942 genes, indicating that a differentiated cell is not only characterized by the proteins it expresses, but also by comparative levels of expression. Both mRNA and protein levels have also been quantified in cell culture (Figure 1). ${ }^{[2]}$ While the number of mRNA transcripts per cell remains low (RNA median of 17), the number of proteins translated per cell is higher (protein median of 50,000), ranging from less that 100 to up to $10^{7}$ molecules/cell. Highly abundant proteins are typically involved in cell structure and in "basic" metabolic activities. Low abundant proteins (e.g. nuclear transcription factors) usually regulate essential cellular functions. Their numbers are precisely regulated by genetic 
To link to this article (1) Chiper, M.; Niederreither, K.; Zuber, G. Transduction Methods for Cytosolic Delivery of Proteins and Bioconjugates Into Living Cells. Adv. Healthcare Mater. 2018, 7, e1701040.

Doi : 10.1002/adhm.201701040

expression/repression, but also by protein degradation mechanisms and/or posttranslational modifications. An important component of proteome diversity lies within protein localization, also globally quantified. ${ }^{[1]}$ Membrane-associated or secreted proteins account for about $40 \%$ of the genome's protein coding capacity. The remaining $60 \%$ of proteins are confined inside the cell by the plasma membrane bilayer, which physically regulates inflow and outflow of water-soluble macromolecules.

Intracellular proteins, particularly those with nuclear localizations, exert important cellular functions. Strategies to facilitate intracellular delivery of exogenous proteins, nucleic acids, and/or entire genes will have clear biomedical applications, especially those providing routes for inducible and selective gene expression. ${ }^{[3]}$ In some cases overexpression of a single exogenous protein may be directly therapeutic. In other cases, such as regenerative medicinal applications, a dosage and temporally precise delivery of multiple transcription factors is likely required. Temporal and dosage control of protein level inside cells cannot be easily achieved with DNA transfection, predominately because it is almost impossible to accurately control the amplification steps. Namely, exogenous DNA transfection cannot control levels of transcription (controlling mRNA quantity) nor amounts of RNA translation (controlling protein quantity). Direct cytosolic delivery of therapeutic proteins appears an interesting alternative to address this issue. A complementary strategy is to interfere with protein function using high affinity binding molecules and antibodies derivatives, often aimed to block a malicious protein function (e.g. an oncogenic or neurodegenerative protein). An example of this strategy is when recombinant antibody fragments (known as intrabodies) are expressed inside the cells (using DNA transfection) and retained in the endoplasmic reticulum (ER). Here intrabodies can entrap their protein target when it passes through the ER, hence modulating overall cell behavior. ${ }^{[4-5]}$ Full antibodies, though, cannot be easily expressed in mammalian cells, because antibody excretion is required for an accurate folding. Techniques 
for direct antibody/intrabody delivery into the cytosol are required. Finally, the transfection of genetic materials into humans raises ethical issues, with the risk of contaminating the human genome with human-made nucleic acid fragments.

Direct delivery of proteins inside the cell is not an easy task for the following reasons. First, each protein is unique in terms of size, surface charge, function, and fragility. Production in sufficient quality and quantity is not always feasible. Second, the lipid bilayer surrounding the cell offers an effective barrier to hydrophilic macromolecules. Third, the cell senses damages to the plasma membrane - which can overwhelmingly trigger irreversible cell death mechanisms. Nonetheless, the challenge of delivering proteins inside cells has been addressed by several approaches, some showing clear success.

For example, nanomaterials have been shown to effectively aide intracellular protein delivery (reviewed in $2011^{[6]}$ and $2014^{[7]}$ ). Moreover, the promises and pitfalls of intracellular protein delivery $^{[8-9]}$ and approaches for intracellular delivery of antibodies have also been reviewed. ${ }^{[10]}$

In this progress report, we complement previous reports and present diverse approaches for protein delivery, examining their applications within the scope of the recent advances in the field.

\section{Improving Protein Transduction by Increasing Cell Membrane Permeability}

\subsection{General Concept}

Mammalian cells can sustain to some degree plasma membrane damage, hence transient holes can be made without impacting cell viability. ${ }^{[11]}$ Soluble proteins can then enter the viscous cytosol by passive diffusion according to Fick's law of diffusion (Figure 2). This equation stipulates that particles/proteins move smoothly from an area of higher concentration to an area of lower concentration. The speed of the process depends on a 
diffusion coefficient (D), which is inversely proportional to the hydrodynamic radius of the macromolecule and to the viscosity of the medium. In other words, large macromolecules diffuse slower than smaller molecules, with diffusion slowed even more in a viscous solution. The cytosol is a viscous (e.g. macromolecules-crowded) medium and its viscosity can be determined $\left(\mu: 2.8 \mathrm{mPa}_{\mathrm{s}}{ }^{-1}\right) .{ }^{[12]}$ However, considering the cytoplasmic volume as a pure homogeneous viscous solution is a simplistic view, since the cytoplasm is also packed with a network of cytoskeletal filaments. Protein binding to these cytoskeletal components slows protein diffusion considerably. Increasing protein hydrodynamic radius decreases the diffusion coefficient (D) in the cytosol $\left(\mathrm{D}_{\text {cytosol }}\right)$ relative to that in water $\left(\mathrm{D}_{\text {water }}\right)$ (Figure 2B). ${ }^{[13]}$ The $540 \mathrm{kDa} \beta$-galactosidase protein even appears immobile in the cytosol, whereas macromolecules with hydrodynamic radii of 15-20 nm (dextrans of different molecular weights $)$ that do not bind to the cytoskeleton can still diffuse $\left(\mathrm{D}_{\text {cytosol }} / \mathrm{D}_{\text {water }}\right.$ of 0.1$) .{ }^{[13]}$ Certain proteins (lactalbumin or bovine serum albumin) likely bind to the cytoskeleton as seen by lower than anticipated $\mathrm{D}_{\text {cytosol }} / \mathrm{D}_{\text {water }}$ ratios (see Figure 2B). ${ }^{[13]}$

\subsection{Physical Methods}

Physical delivery methods are considered the most straightforward approaches to directly deliver proteins to the cytosol. Over the years, several techniques have been developed such as electroporation, sonoporation, microinjection, and more recently mechanical deformation and microfluidics electroporation. The common point of these methods is their reliance on specific instrumentation.

Microinjection of protein solutions through the plasma membrane with a syringe is a classic powerful method. ${ }^{[14-15]}$ Solutions can be injected either into the cytosol or within the nucleus. Microinjection is a preferred method when temporal and quantitative precision are 
To link to this article (1) Chiper, M.; Niederreither, K.; Zuber, G. Transduction Methods for Cytosolic Delivery of Proteins and Bioconjugates Into Living Cells. Adv. Healthcare Mater. 2018, 7, e1701040.

required for success, ${ }^{[12]}$ but it cannot practically be used when a large number of cells require protein delivery.

Electroporation is an other method for transduction of macromolecules. ${ }^{[16]}$ For this, cells are placed between 2 electrodes in a solution containing the protein to be delivered. A brief high voltage electric pulse is applied, which creates transient holes in the plasma membrane. Soluble proteins and other solutes can then bi-directionally diffuse through the plasma membrane holes according to the Fick's law of diffusion. Electroporation effectiveness depends on the robustness of the cell, protein parameters, transduction medium, and electrical pulse voltage. ${ }^{[17]} \mathrm{A}$ vast improvement in this method was seen with new devices allowing electroporation of non-adherent or freshly trypsinized adherent cells in a microsyringe, rather than classic methods using a cuvette. With the Neon ${ }^{\circledR}$ device (Life Technology), the group of E. Weiss delivered at least 17 monoclonal $150 \mathrm{kDa}$ antibodies, including blocking antibodies (anti-oncoprotein E6, anti-DNA polymerase $\alpha$ ) and peptideantibodies conjugates at an almost $100 \%$ efficiency in HeLa cells. ${ }^{[18]}$ For example, monoclonal antibodies targeting the DNA polymerase $\alpha$ (one blocking, and the other not blocking enzyme function) were both equipped with a nuclear localization signal (NLS) peptide. The conjugates were then electroporated into HeLa cells (Figure 3). Both antibodies were seen to accumulate into the cell nuclei, but only the blocking monoclonal antibody specifically impaired cell viability. The electroporation method can also be effectively used to introduce antibody fragments. ${ }^{[19]}$ Quantitative analysis confirmed that transduction efficiency obeys the Fick's law of diffusion. The amount of transduced proteins correlates with the protein concentration gradient, and transduction quantity increased when antibody size was reduced from $150 \mathrm{kDa}$ (full antibody size) to $50 \mathrm{kDa}$ (Fab antibody fragment size). For HeLa cells, about $10^{5}$ to $10^{6}$ proteins can be delivered per cell at an external protein concentration of $10 \mu \mathrm{M}$, allowing directly cytosolic delivery of most proteins (generally avoiding intracellular 
vesicular entrapment). This application allows real-time imaging of live cells, combined with selective silencing of protein function with specific antibodies. Key to this strategy of effective blockade, antibody concentration should exceed that of the targeted protein. Hence, only proteins present at concentration below $10^{5}-10^{6}$ molecules/cell are good targets. For example, DNA polymerase $\alpha$ (DNA pol $\alpha$, Q8CAT7) quantity is estimated at 50,000 copies per cell ${ }^{[2]}$, with electroporation experiments demonstrating a blockade of DNA polymerase $\alpha$ function using an anti-DNA polymerase $\alpha 50 \mathrm{kDa}$ antibody fragment (Fab). ${ }^{[19]}$ This suggests that any intracellular proteins with concentrations below 50,000 copies/cell (or 69 $\mathrm{nM}$ with an HeLa cell volume of $1.2 \mathrm{pL})^{[20]}$ can be successfully targeted with electroporated blocking antibody derivatives. Hence compared with other protein delivery techniques, electroporation appears to be the most robust and reliable protein delivery method for in vitro cell cultures. ${ }^{[21]}$ The potential use of electroporation for in vivo therapeutic applications is limited primarily because electrodes are invasive. Proof of concept was nonetheless obtained in animal models. ${ }^{[22-24]}$

Another technique to increase plasma membrane permeability is the use of intense light pulses, ${ }^{[25]}$ a technique termed optoporation. ${ }^{[26]} \mathrm{Wu}$ et al. performed optoporation on cultured cell lines to test $\beta$-lactamase and antibody delivery, demonstrating efficient protein transduction could occur without reducing cell viability. ${ }^{[27]}$ To date, more studies are required to confirm the overall utility of optoporation, within the potential to be as, or even more efficient than electroporation for in vitro applications. Future developments of light-sensitive chemicals to enhance delivery efficiency are feasible advancements for broader therapeutic applications. One drawback is that light does not deeply penetrate into mammalian tissues, ${ }^{[28]}$ but superficial light application is clearly possible on surface of the skin or in tissues with cavities (e.g. the bladder). 
Another advancement is the use of microfluidic technology, interesting for cytosolic protein delivery. Cells are forced to pass through a capillary tube with a diameter inferior to that of the cell. A mechanical constriction occurs, allowing flow adjustment mediating the generation of transient holes in the plasma membrane, which apparently do not reduce cell viability. Here, membrane permeabilization is sufficient for the transduction of various macromolecules and antibodies into HeLa cells. It allows effective conversion of human fibroblasts to generate induced embryonic stem cells with four transcription factors (Oct4, Sox2, c-Myc and Klf-4). ${ }^{[29]}$ This microfluidic membrane deformation method was also used to deliver the Cas9 enzyme, along with other nucleic acids in various cancer cell lines. ${ }^{[30]}$ It should be noted that this method relies on a device containing tubes of small diameters, which can be costly to build and easily clogged.

A $\mathrm{NaCl}$ hypertonic medium can also be used to permeabilize the plasma membrane of both primary cells and human embryonic cells. Addition of glycine and glycerol allows efficient transduction and low cell mortality, helping cells overcome osmotic stress. Inclusion of zwitterions such as $\gamma$-amino-butyric acid or non-detergent sulfobetaines also enhances protein solubility. ${ }^{[31]}$

Chemicals and bacterial pore-forming toxins can also be used for improved protein transduction. Streptolysin O (SLO) is a bacterial exotoxin that inserts in the plasma membrane. It then oligomerizes into aggregates, forming larges pores with diameters up to $35 \mathrm{~nm}$. In principle, the outcome is cell death. Nevertheless, at low quantities these pores can be resealed by addition of calcium, restoring cell viability. As high as $10^{5}-10^{6}$ of BSA (a $67 \mathrm{kDa}$ protein with a hydrodynamic diameter of $6.4 \mathrm{~nm}$ ) can be trapped into viable resealed human monocytic THP-1 cells. Proteins of molecular weights larger than $100 \mathrm{kDa}$ (hydrodynamic diameter $>7.6 \mathrm{~nm}$ ), though, were unable to pass through SLO-generated pores. ${ }^{[32]}$ 
Listeriolysin O (LLO) is another pore-forming toxin. Unlike streptolysin O, listeriolysin $\mathrm{O}$ responds to $\mathrm{pH}$ variation and forms pores specifically in endocytic vesicles. Using this LLO approach for in vivo protein delivery, an affinity domain for the epidermal growth factor receptor (EGFR) was coupled to the plant ribosome-inactivating protein gelonin. Hence by efficient binding to the cell surface EGFR in cells expressing high receptor levels $\left(3 \times 10^{6}\right.$ EGFR/cell), fusion proteins can be engulfed in endosomes. Hence, LLOs form pores and increase the cytosol-exclusive activity of gelonin. ${ }^{[33]}$ In this investigation, amplification of the LLO activity using the EGFR targeting approach was also seen in vivo in a tumor xenograft model. ${ }^{[33]}$

\subsection{Conclusions for this section}

Important progress has been recently made in protein transduction techniques using permeabilization of the plasma membrane in cultured cells, allowing improved cell viability. These methods have been evaluated for cytosolic protein delivery efficiency and suggest that novel devices will be important improvements, also useful for investigating cellular mechanisms of protein import.

\section{Transduction by Covalent Modification of a Protein}

\subsection{General Concept}

In 1994, Fawell and colleagues ${ }^{[34]}$ synthesized a thiolated peptide containing a large portion of the human immunodeficiency virus (HIV) TAT Protein (sequence 37-72). This peptide was conjugated to several proteins ( $\beta$-galactosidase, horseradish peroxidase, RNAse A) using succinimidyl 4-(N-maleimidomethyl)cyclohexane-1-carboxylate (SMCC) as the thiol to the protein's amine crosslinker. When incubated with cells, each conjugate was seen to readily enter into the cytoplasm, suggesting that any protein can be delivered inside a cell by simple covalent conjugation of a Cell Penetrating Peptide (CPP). This initial study has 
To link to this article (1) Chiper, M.; Niederreither, K.; Zuber, G. Transduction Methods for Cytosolic Delivery of Proteins and Bioconjugates Into Living Cells. Adv. Healthcare Mater. 2018, 7, e1701040.

Doi : 10.1002/adhm.201701040

spurred considerable interest in the scientific community to develop protein derivatives with cell-penetrating abilities.

\subsection{Biotechnological Engineering for Transduction of a Fusion Chimera}

In a biotechnology-driven strategy, a protein is produced by the genetic engineering of a chimeric gene (Figure 4). To facilitate purification, most recombinant proteins are first tagged with a poly-histidine tail, allowing affinity chromatography purification using Niimmobilized resin. Then, transduction domains improving entry (CPPs), and other required sequences are engineered into the chimera. After DNA plasmid construction, the recombinant protein is then expressed (usually in E. Coli.), purified, and then simply added to target cells. While the process is relatively straightforward, outcomes in terms of transduction efficiency are variable because the transduction domain can alter protein colloidal and functional behaviors, and/or the protein can diminishes the activity of the transduction domain. Despite these hurdles, several recombinant CPP-fused cytosolic/nuclear active proteins have been shown to function when added to cells (Table 1). The CPPs are generally highly cationic entities that bind by electrostatic interactions to sulfated proteoglycans present in large quantities on the external face of the plasma membrane of many cell types. CPPs then act on the membrane bilayer to promote either immediate permeabilization, or delayed entry via the endovesicular pathways. ${ }^{[35]}$ The actual site and temporal time frame in which CPP exert their action is difficult to ascertain and still currently debated. ${ }^{[36]}$ This dilemma exists because whether CPPs allow direct membrane translocation or delayed indirect entry cannot be distinguished because the plasma membrane continuously recycles with the vesicular compartment. The CPP-induced mode of entry could be a function of either the CPP itself, protein concentration, transport cargo, physicochemical properties of the final compound, cell type, and/or overall experimental conditions. ${ }^{[37]}$ 
The minimal YGRKKRRQRRR sequence originating from the Human Immunodeficiency Virus (HIV) TAT protein is the most commonly employed transduction domain. This TAT peptide was effectively fused to $\mathrm{P} 27^{\mathrm{kip} 1} \mathrm{Cdk},{ }^{[38-39]} \beta$-galactosidase, ${ }^{[40]} \mathrm{Cre}$ recombinase, ${ }^{[41]}$ a Bcl-XL variant (the FNK), ${ }^{[42]}$ and the transcription factor cocktail used for stem cell reprograming, ${ }^{[43-[44] 45]}$ in all cases allowing efficient protein entry. Notably intraperitoneal injection of the TAT- $\beta$-galactosidase fusion protein results in protein delivery to all adult mouse tissues, notably crossing the blood brain barrier. ${ }^{[40]}$ No toxicity, assayed by analysis of tissue distribution and bioavailability, was detected. The TAT peptide is a cationic peptide, accumulating in the cell nucleus. This property may be interesting for delivering nuclear proteins, but might be undesirable for cytosolic protein delivery, hence a variant of TAT with a cytosolic tropism has been developed. ${ }^{[46-47]}$ Oligoarginine $\left(\mathrm{R} 7,^{[48]} \mathrm{R} 11^{[49]}\right.$ ), antennapedia protein transduction domain, ${ }^{[50]}$ penetratin, ${ }^{[51]}$ or Pep- $1^{[52-53]}$ have also been used to facilitate transduction of proteins. New CPPs are currently being developed. These include the ZEBRA CPP ${ }^{[39-54]}$ human nuclear body protein SP140-like protein, ${ }^{[55]}$ and even the supercharged +36 GFP (scGFP) which is fused to several proteins (mCherry, Ubiquitin, and Cre-recombinase) allowing fluorescence detection, cytosolic delivery, and targeted gene recombination. ${ }^{[56]}$ Resurfacing the VL domain of $\operatorname{IgG}^{[57-58]}$ or single domain antibodies or "nanobodies" deriving from alpaca ${ }^{[59]}$ appears also promising, particularly in animal models targeting the brain. ${ }^{[60]}$

For the CPP-proteins which tend to accumulate in intravesicular compartments, the challenge is to minimize residence in this aggressive environment. ${ }^{[61]}$ To avoid/limit vesicular entrapment, CPP-proteins have been co-incubated with lysosomotropic molecules (chloroquine, sucrose $)^{[62]}$ or with fusogenic peptides. Improvement of efficiency was achieved specifically by incubation of TAT-Cre recombinase with an independent peptide consisting in the fusion of TAT with the fusogenic domain from influenza hemagglutinin (HA). ${ }^{[41]}$ Protein 
To link to this article (1) Chiper, M.; Niederreither, K.; Zuber, G. Transduction Methods for Cytosolic Delivery of Proteins and Bioconjugates Into Living Cells. Adv. Healthcare Mater. 2018, 7, e1701040.

Doi : 10.1002/adhm.201701040

fusions incorporating sequences of the HA fusogenic peptide and the TAT-peptide were also designed. The HA-TAT-Bcl-xL ${ }^{[63]}$ and HA-TAT-Ndi1 ${ }^{[64]}$ chimeras efficiently protect organs from ischemia/reperfusion injury in animal models. More recently, Sudo et al., identified a 19 residue-long peptide corresponding to position 322 to 340 of the human protein Syncytin1 that has also membrane-disrupting activities. When this peptide is combined with TAT-EGFP, a 90 -fold increase in protein transduction into cancer cell lines was observed. ${ }^{[65]}$ A systematic screen of peptides with membrane penetrating activity was performed by $\mathrm{Li}$ et al. finding enhanced transduction efficiency of supercharged GFP-recombinase fusion in a cell line model. ${ }^{[66]}$ The GLFDIIKKIAESF peptide (Aurein 1.2) was found as the most effective membrane penetrating peptide. Its effectiveness was maintained when the sequence was fused to a supercharged cationic GFP-recombinase.

Efficiency CPP-protein association onto cell surfaces is highly cell type-dependent. This is unfortunately quite low in embryonic stem cells or induced pluripotent stem cells compared to somatic cells. ${ }^{[67]}$ To increase CPP-protein binding to stem cell surfaces Dixon et al. selected a heparin-binding peptide (HBD) fused with oligoarginines, then attached to different proteins (Cre recombinase, neomycin phosphotransferase, cytochrome C, $150 \mathrm{kDa}$ IgG, and the NANOG and MYOD transcription factors). ${ }^{[67]}$ This strategy increased plasma membrane association leading to vastly improved transduction efficiency.

\subsection{Chemical Engineering of CPPs to Enhance Transduction Activity}

CPPs can be further modified with non-natural aminoacids to become synthetic entities. Examples of these chemical structures are presented in Figure 5. In contrast to peptides, synthetic compounds are not prone to extensive enzymatic degradation by proteases. ${ }^{[68]}$ They can also enhance the specific activity of the CPPs. The polyethylenimine (PEI) polymer is well known for its ability to facilitate delivery of DNA plasmids into 
To link to this article (1) Chiper, M.; Niederreither, K.; Zuber, G. Transduction Methods for Cytosolic Delivery of Proteins and Bioconjugates Into Living Cells. Adv. Healthcare Mater. 2018, 7, e1701040.

mammalian cells. ${ }^{[69]}$ PEI assembles with nucleic acids into a polyplex. This cationic polyplex then binds to the cell surface and is then directed into endosomes. A hypothetical model stipulates that PEI buffers the acidification of endosomes like a "proton sponge". This event builds osmotic pressure inside the endosome, promoting an eventual rupture of the endosomal lipid membrane and liberation of the nucleic acids in the cytosol. ${ }^{[70]}$ Covalent conjugation of the "proton sponge" $\mathrm{PEI}^{[71]}$ to proteins results in endosomal (and also cytosolic) internalization of cationized proteins. Both the high molecular weight of PEI and the polymer polydispersity make characterization of PEI-protein conjugates both challenging and variable. Substitution of the PEI with a tetra-guanidinium dendrimer can somewhat resolve difficulty in identifying the conjugate. ${ }^{[72]}$

The easiest way to conjugate domains onto a protein is by formation of amide bonds. These bonds might affect protein stability and activity, hence trace-less and bio-responsive bonds were developed. The group of E. Wagner developed a pH-sensitive bifunctional linker (the azidomethyl-methylmaleic anhydride linker) to introduce azido groups onto protein amino groups to covalently graft sequence-defined cationic oligomers. Biologically, this modification allowed very high RNaseA conjugate uptake, resulting in significant RNAseAmediated cell death. ${ }^{[73-74]}$ The linker can be cleaved within mildly acidic endosomes to liberate the original protein, without leaving any chemical trace of the conjugation. Another bond enabling intracellular release of the cell-penetrating domain from the protein is the redox sensitive disulfide bond. ${ }^{[75-76]}$ In the extracellular oxidizing medium the disulfide bond remains intact, but it is cleaved into thiols in the reducing intracellular compartment. ${ }^{[77]}$ This redox sensitive disulfide bond strategy was particularly effective for introduction of transcription activator-like effector nucleases (TALENs) into cells. While TALENs can not be easily fused to CPPs, nonetheless, they contain an easily accessible surface cysteine. ${ }^{[78]}$ This cysteine was used to conjugate a cell-penetrating $\mathrm{C}(D)-\mathrm{R}_{9}$ poly-Arg, allowing cell entry of 
R9-TALEN and a subsequent intracellular release of $C(D)-R_{9}$ and the fully active thiolcontained TALEN protein.

CPP activity can also be optimized by diminishing its motion via cyclization. ${ }^{[79]}$ As an illustration, the cyclo-F $\Phi$ RRRRQ (where $\Phi$ is L-2-naphthylalanine) was condensed to cysteinamide to acquire a pending thiol. This chemical domain was then exquisitely conjugated to a GFP variant via a disulfide bond using the Sfp phosphopantetheinyl transferase technology. ${ }^{[80]}$ This selected synthetic transduction domain showed enhanced transduction efficiency in comparison to the natural linear TAT peptide. The benefits of this CPP cyclization has been independently confirmed. ${ }^{[81]}$ Here, CPP-protein attachment did not require a reducible disulfide linkage, but rather a cyclic TAT peptide that was conjugated to alkyne-GFP conjugates using click chemistry. Dowdy et al. used a similar disulfide bond to link a thiol-containing GFP variant to a synthetic tail containing the TAT CPP and a membrane-perturbing peptide of sequence $-\mathrm{GWWG}^{\left[{ }^{82]}\right.}$ They then investigated the impact of the distance between the TAT CPP and the GWWG sequence using polyethyleneglycol spacer of different lengths. They found that a spacer of 6 ethyleneglycol units provided the best transduction activity.

\subsection{Conclusions for this section}

Investigations confirm that addition of CPP to a protein is a feasible approach for delivering exogenous proteins into mammalian cells. The use of CPP-fused proteins for therapeutic applications has not been successful, mainly due to low transduction yield and technical issues with the preparation and purification of recombinant CPP-fused proteins. ${ }^{[83]}$ In current clinical trails, CPPs are being considered for the delivery of smaller entities, such as peptides and/or chemicals. ${ }^{[84]}$ Current data nonetheless suggest that CPP-based conjugates are 
useful for cell reprogramming (where cells can be manipulated ex vivo) and where a small amount of protein (e.g. a transcription factor) could have a dramatic impact.

\section{Transduction with Organic Supramolecular Systems}

\subsection{General Concept}

Exogenous modifications of proteins could produce fundamental alterations in structure that result in irreversibly lost of activity during protein purification. A different strategy to overcome this problem is instead of covalently linking a protein to a carrier, one can bind the protein by non-covalent interactions to form a supramolecular assembly with virus-type features (Figure 6). The carrier is usually a cationic amphiphilic molecule, which when provided in excess forms positively charged complexes containing the proteins of interest. When added to cells, the cationic complexes strongly anchor to anionic proteoglycans. Since these surface proteoglycans are abundant on most cells, electrostatic interactions allow complex anchorage. This is followed by uptake into endocellular vesicles. Inside vesicles, the protein-confined complexes undergo $\mathrm{pH}$ acidification. The composition of the lipid membrane surrounding the complexes also gradually changes. Collectively, these changes are exploited by the carrier to trigger endocellular vesicle lysis, allowing the macromolecule complex to access to the cytosol.

\subsection{Cationic Carriers via Complex Formation}

Cationic carriers with known DNA transfection abilities were also tested for protein delivery capacity. Examples of carriers with demonstrated efficiencies are shown in Figure 7. The dioctadecylglycylspermine (DOGS) is a DNA transfection cationic lipid with intrinsic membrane-perturbing activities. It mediates anionic proteins delivery by a similar mechanism as nucleic acids, but those efficiency depends on individual characteristic of the transfected 
protein. ${ }^{[85]}$ Lipid compositions containing the fusogenic dioleoyl phosphatidylethanolamine (DOPE) are also effective. Zelphati et al. demonstrated that BioPORTER ${ }^{\mathrm{TM}}$ can deliver functional enzymes (caspase, $\beta$-galactosidase) or antibodies into the cytoplasm of living cells. ${ }^{[86]}$ The multipurpose SAINT-2 complex improved protein delivery when complexes were incubated in presence of serum. ${ }^{[87]}$ Other cationic lipids and formulations have been developed to address specific issues. ${ }^{[88-93]}$ Some reliable and cost-effective formulations have been commercialized for protein delivery in in vitro cell culture models (for instance: AbDeliverIN $^{\mathrm{TM}}$, PULSin $\left.{ }^{\mathrm{TM}}\right)$. Delivery conditions have to be semi-empirically optimized for each protein. When optimized, these cationic carriers seem more reliable than CPP-protein conjugation approach for cell culture protein delivery. ${ }^{[94]}$ They have a history of successes, particularly for cytosolic antibody/epitope introduction into living cells $^{[95-100]}$ or for synthetic antibody-gold particle conjugate transduction. ${ }^{[101]}$ However a recent comparison indicated that protein delivery reagents are currently less efficient compared with novel electroporation techniques. ${ }^{[21]}$

Non-lipid amphiphilic carriers are also effective for protein delivery. A cationic bolaamphiphile was reported to successfully deliver KLF4, Nanog, NR5A2, and Sox2 reprogramming factors into human fibroblasts. ${ }^{[102]}$ Hydrophobic PEI with disassembly abilities at $\mathrm{pH} 6.0$ (specific to endosomes) have been developed for siRNA ${ }^{[103]}$ and oligonucleotide $^{[104]}$ delivery. The pyridylthiourea-modified $25 \mathrm{kDa}$ PEI $(\pi \mathrm{PEI})$ is an excellent siRNA transfection agent for cell cultures. It has demonstrated in vivo efficiency in a liver tumor xenograft model when polyplexes were injected directly into tumors. ${ }^{[105]}$ The $\pi$ PEI also increased delivery of antibodies against a crucial epitope of the EG5 kinesin spindle protein, which allows accurate chromosome segregation during mitosis (Figure 8). ${ }^{[106]}$ The same perturbation of chromosome segregation was observed either via siRNA-mediated mRNA fragmentation or via cytosolic antibody binding to EG5. The level of cell disruption was 
nonetheless lower for the $\pi$ PEI-delivered antibody (70\% cell death) compared to the $\pi$ PEIdelivered siRNA $(>95 \%$ ), likely because the number of EG5 proteins (about 24,000 molecules/cell) exceed the number of corresponding mRNAs (about 10 EG5 mRNA/cell). ${ }^{[2]}$ In a slightly different approach, the redox and pH-sensitive S-Polyethyleneglycol-S'-poly(2diethyl aminoethylmetacrylate) aided delivery of cytochrome $\mathrm{C}$ in several tumor cell lines mediating cytochrome $\mathrm{C}$-induced cell death. ${ }^{[107]}$

Peptides have also been developed as carriers for protein delivery. Morris et al. initially designed a 21 residue CPP sequence: KETWWETWWTEWSQPKKKRKV (Pep-1), combining a hydrophobic segment to a cationic domain ${ }^{[108]}$ and later optimizing the peptide sequence. ${ }^{[109]}$ The Pep-1 is commercially available under the name Chariot $^{\mathrm{TM}}$ and has been used for caspase 3 and protein kinase A subunit delivery in lung tissue. ${ }^{[110-111]}$ Further in vitro investigations suggested that additional improvement of the peptide sequence design may be obtained by enlarging hydrophobic pockets, privileging aromatic and positive residues. ${ }^{[112-115]}$ A peptidic backbone is not mandatory, hence artificial backbones function as well. Condensation of guanidinobenzoic acid to polyamidoamine dendrimer gave a dendrimer with robust intracellular protein delivery ability in cultured cells and with in vivo potential for saporin-mediated tumor growth diminution in a tumor xenograft model. ${ }^{[116]}$ Finally, oligomers made from hydrophobic (benzyl) and cationic (guanidinium) oxanorbornene monomers were also able to deliver proteins into living cells with the transduction yield depending on the overall hydrophobicity. ${ }^{[117-118]}$

\subsection{Solutions for Reliable Complex Formation}

As previously indicated, robust electrostatic associations between cationic carriers and proteins can be hindered by physicochemical variability of a given protein. To improve electrostatic associations and transduction reliability, one approach is to attach an anionic 
domain to the proteins (Figure 9). Anionic GFP was fused to several proteins (Recombinase, TALE) before association with a carrier, which then ensured reliable transduction. ${ }^{[119]}$ Anionic proteins can be also obtained by chemical conjugation to oligonucleotides, ${ }^{[120]}$ hyaluronic acids ${ }^{[121]}$ or by charge reversion of the amines of lysine into citraconate amide or cis-aconitate amide. ${ }^{[122-123]}$ The advantage of the latter modification resides in its acidsensitive link. Passage into acidic intracellular vesicular compartments may hence regenerate the native protein. Reliable and enhanced delivery was observed, but comes at the cost of an extra protein-modification step. Fusion of an oligohistidine peptide (His-tag) to protein is a common practice for purification of recombinant proteins. The non-covalent and acidsensitive association of the His-tag to chelated nickel has been used, as well as to congregate His-tagged proteins onto a polyanion to enhance association with a cationic carrier, subsequently increasing cytosolic delivery. ${ }^{[124]}$ Further sophistication of this technique includes formulating lipid-oligomer nanoparticle complexes, where the added helper lipids enhance the serum stability of nanoparticles. ${ }^{[125]}$

\subsection{Protein Encapsulation in Synthetic Shells for in vivo Administration}

As previously indicated, the lipid plasma membrane represents an important barrier to protein import. While significant improvements in cytosolic protein import can be made using in vitro cultured cells, these systems will not address the complexity of intact animal models. Improving the pharmacological behavior of the carrier/protein complex in whole organisms will require controlling complex's size, stability, and superficial charge. Solutions on how to control the size of supramolecular complexes to enhance in vivo compatibility may improve gene delivery. Monomolecular condensation of a single DNA plasmid by in situ polymerization of bis-thiolated detergent produces encapsulated DNA nanoparticles that can circulate in the blood 30 minutes after injection. ${ }^{[126]}$ This concept was further improved by the 
To link to this article (1) Chiper, M.; Niederreither, K.; Zuber, G. Transduction Methods for Cytosolic Delivery of Proteins and Bioconjugates Into Living Cells. Adv. Healthcare Mater. 2018, 7, e1701040.

Doi : 10.1002/adhm.201701040

group of E. Wagner through development of library of thiolated oligomers. ${ }^{[127]}$ Selected thiolcontaining cationic oligomers encapsulated GFP nanobodies into 20 nm-diameter particles. ${ }^{[128]}$ These particles were effectively internalized into cells, releasing the nanobody into the cytosol, where it bound both GFP and GFP-fused proteins. In principle, this nanoparticle strategy may allow whole organism protein targeting. ${ }^{[125]}$

The chemistry of the shell surrounded protein nanocapsules was further investigated by Yan et al. (Figure 10A). To control the formation of the shell around each single-protein, several types of vinyl monomers were condensed onto lysine side chains of proteins by amide bond formation. ${ }^{[129]}$ The vinyl-equipped proteins were then copolymerized with cross-linkers in aqueous media to "wrap" each single protein within a thin polymer shell. By varying the chemical structure of the cross-linkers, intracellular nanocapsule stability or proteolytic degradation can be controlled. Thus, the main advantage of this synthetic approach is that non-degradable nanocapsules can be prepared, which display long term-stability with protection of the encapsulated proteins. Degradable nanocapsules, on the other hand, allow the encapsulated proteins to become active inside the cell immediately after the shell is destroyed. Successful intracellular delivery of encapsulated GFP, BSA, horseradish peroxidase, superoxide dismutase, and caspase 3 has been reported. ${ }^{[129]}$ The functionality of cytosolic caspase 3 was measured in in vitro HeLa cell culture, comparing degradable versus non-degradable nanocapsule action. Only degradable nanocapsules containing caspase 3 could trigger $40 \%$ HeLa cell apoptosis.

Other methods avoiding covalent protein modification have been tested. ${ }^{[130]}$ Several types of monomers can be absorbed onto proteins by van der Waals interactions (Figure 10B), allowing subsequent in situ polymerization with various cross-linkers. The generated noncovalent shell allowed the variation of nanocapsule solubility, as well as further modification for active targeting. The chemical process was performed via copper free click chemistry in 
To link to this article (1) Chiper, M.; Niederreither, K.; Zuber, G. Transduction Methods for Cytosolic Delivery of Proteins and Bioconjugates Into Living Cells. Adv. Healthcare Mater. 2018, 7, e1701040.

Doi : 10.1002/adhm.201701040

aqueous media. The stability of redox sensitive nanocapsules ${ }^{[131-132]}$ and protease-sensitive nanocapsules ${ }^{[133]}$ were also investigated.

This protein nanocapsule methodology can be used to target cancer tissues, by blocking neoplastic tumor promoters, such as by using an anti-Her2 antibody (for targeting Her2expressing cancer tissues) and by re-expressing the tumor suppressor protein $\mathrm{p} 53$-frequently lost during cancer progression. Nanocapsules containing the p53 protein were prepared with redox sensitive crosslinkers N,N'-bis(acryloyl)cystamine, acrylamide and Nazidodeca(ethylene glycol)ethylacrylamide. The azido-containing nanocapsule were then equipped with a ScFv antibody directed against HER2 for targeting SK-BR3 tumor breast cancer overexpressing this cell surface receptor. Findings that protein nanocapsules could selectively accumulate desired proteins into the cytosol of tumors was demonstrated by encapsulation of the tumor suppressor protein p53 into a luteinizing hormone releasing hormone (LHRH)-grafted nanocapsule. ${ }^{[130]}$

Chen et al. reported a different type of protein delivery system for active targeting. The authors developed a reduction-sensitive fluorescent hyaluronic acid (HA) nanogel by combining the inverse nanoprecipitation technique with catalyst free "tetrazole-alkene" photoclick-crosslinking chemistry (Figure 10C). ${ }^{[134]}$ The bio-responsive nanogel could entrap into its three-dimensional network one of the two apoptotic proteins (cytochrome $\mathrm{C}$; granzyme B). Overall, the approach seems to be biocompatible, conserving the activity of the encapsulated proteins, even if large amounts of acetone were employed during the inverse nanoprecipitation step. Along with protecting the protein, HA promotes endocytosis of the CD44 receptor upon binding, a receptor which is overrepresented on the surface of several cancer cells. ${ }^{[135]}$ In principle, these HA protein nanogels may be good vehicles to target proteins to specific tumor site, enhancing both uptake and retention of therapeutically delivered molecules. Granzyme B, an apoptosis mediator inactivating a variety of cytosolic 
proteins, was loaded onto HA nanogels. Granzyme B at a low dosage (3.8-5.7 nmol of GrB equivalents $/ \mathrm{kg}$ ) suppressed CD44+ tumor xenograft growth in mice, with minimal side effects. Tumor selectivity may be further enhanced by addition of a ligand (GGGGGYHWYGYTPQNVI named GE11 peptide) targeting the Epidermal Growth Factor Receptor (EGFR). This produces a CD44/EGFR dual-targeted delivery system. ${ }^{[136]}$ Here nanogels were prepared by a similar established strategy as shown in Figure 10C, employing the tetrazoles-containing HA derivatives, GE11 peptide/tetrazole, and cystamine methacrylate. This generated nanogels with a high loading efficacy for either cytochrome $\mathrm{C}$ or granzyme $\mathrm{B}$, both showing excellent stability in serum and fast release under reductive conditions. These behaviors boosted delivery of granzyme B to ovarian and breast cancers in vitro and in vivo. $^{[136]}$

\subsection{Protein Encapsulation in Exosomes for Cytosolic Protein Dissemination}

Exosomes are natural circulating vesicles that transport macromolecules from the cytosol of one cell to another, ${ }^{[137]}$ which have been explored for their usefulness in encapsulating and transporting exogenous macromolecules into the cytosol of living cells. ${ }^{[138]}$ This technique requires efficient methods of producing large quantities of protein-containing exosomes. Yim et al. proposed an elegant and sophisticated method for loading a transgenic protein (either mCherry, Bax, super-represor IkB, or Cre recombinase) into exosomes. ${ }^{[139]}$ With this, a maximum of two protein molecules per exosome particle were loaded. While loading capacity might appear limited, Cre recombinase-loaded exosomes showed efficient and functional neuronal protein delivery following brain injection. This methodology, though, requires further refinement.

\subsection{Conclusions for this section}


Numerous efforts to optimize the delivery activity of carriers and the efficiency of delivery systems, for both in vitro and in vivo applications, have recently been reported. The current trend is to focus on the development of carriers and non-covalent multifunctional formulations for resolving issues specific to in vivo administration and effectiveness for in vivo pathology models.

\section{Transduction of Unmodified Proteins by Utilization of Intracellular Vesicle Permeability}

An interesting strategy, which cannot be classified in any above-mentioned sections, is to exploit the ability of cell to naturally engulfed proteins into vesicular compartments, where they are entrapped and degraded. An approach is to use peptides that interact with cell lipid membrane, but that become membrane-lytic only when present in intracellular compartments. The fluorescently labeled dimer of the TAT peptide (named dfTAT) was shown to facilitate cytosolic delivery of proteins using this strategy. ${ }^{[140-141]}$ Direct binding of the protein with dfTAT is not required, but the protein and dfTAT must be entrapped together within endocytic organelles. The preferential endocytic activity of dfTAT is likely originating from its affinity to bis-(monoacylglycero)-phosphate, a lipid found in late endosomes. ${ }^{[142]}$ Recently, Akishiba et al. reported that a coiled peptide of sequence IWLTALKFLGKHAAKHEAKQQLSKL-amide (L17E), deriving from the membrane-lytic spider venom peptide M-lycotoxin behaves similarly to dfTAT (Figure 11). ${ }^{[143]}$ A simple substitution of the leucine (L) to a glutamic acid (E) at the position 17 of the M-lycotoxin diminished its lytic activity on the plasma membrane. Yet, when inside intracellular vesicles, this peptide was able to specifically lyse the vesicular lipid bilayer and promote release of any material also present in the vesicle. The ability of the endosomolytic peptide L17E to favor 
To link to this article (1) Chiper, M.; Niederreither, K.; Zuber, G. Transduction Methods for Cytosolic Delivery of Proteins and Bioconjugates Into Living Cells. Adv. Healthcare Mater. 2018, 7, e1701040.

cytosolic entry of endosome-entrapped materials have been successfully tested with fluorescently labeled IgG, Cre recombinase, and saporin/exosome mixture.

\section{Transduction with Exotic Nanoparticles}

\subsection{General Concept}

Inorganic atoms and nanoparticles have unique properties with clear biomedical applications. These carriers might be compatible for systemic administration. ${ }^{[144]}$ External stimuli may selectively sensitize these inorganic-based materials, enacting a tissue-specific approach. Exploiting exogenous nanoparticle technology may be critical in the development of new protein delivery methods suitable for whole-organisms administration.

\subsection{Silica-Derived Materials}

Mesoporous silica nanoparticles bind to cell surfaces and can be directed to lysosomes. ${ }^{[145]}$ Their surface can be easily modified with chemical motifs, hence the pores of the nanoparticles can be adjusted to favor protein anchorage. ${ }^{[145]}$ Niu et al. prepared mesoporous silica nanoparticles with a controlled pore size and then modified the surface with hydrophobic groups to improve membrane activity. ${ }^{[146]}$ These silica particles aided the delivery of several proteins, including an antibody blocking cytosolic pAkt. Silica particles were also chemically modified with an organic layer containing aldehyde moieties. Fluorescently labeled proteins were linked to the silica particle's surface by the formation of acid-labile imine bonds. ${ }^{[147]}$ When resulting conjugates were added to cells, the acidic lysosomes entrapped silica particles, then released fluorescent protein into the cytosol.

\subsection{Gold Nanoparticles}


To link to this article (1) Chiper, M.; Niederreither, K.; Zuber, G. Transduction Methods for Cytosolic Delivery of Proteins and Bioconjugates Into Living Cells. Adv. Healthcare Mater. 2018, 7, e1701040.

Doi : 10.1002/adhm.201701040

Functionalized gold nanoparticles (AuNPs) were used for protein delivery. Aptamers with binding affinity to oligohistidine-tag were conjugated to $15 \mathrm{~nm}$ AuNPs. ${ }^{[148]}$ Several types of His-tagged proteins have been grafted onto the $15 \mathrm{~nm}$ AuNPs via non-covalent interactions with the aptamers. All resulting particles facilitate intracellular delivery of various His-tagged recombinant proteins. The pro-apoptotic His-tagged Bcl-2-like protein 11 loaded onto AuNPs-His-Apt was efficiently delivered, indicated by $40 \%$ cell death in vitro. ${ }^{[148]}$ The system was also evaluated for local and systemic protein delivery in vivo, notably where direct administration into a tumor inhibited its growth. ${ }^{[149]}$

Large sizes AuNPs are not eliminated by glomerular filtration, justifying developing smaller particles with better excretion profiles. ${ }^{[150]}$ In 2010 , the group of Rotello evaluated the usefulness of $2.5 \mathrm{~nm}$ AuNPs assemblies for cytosolic protein delivery. After functionalization with thiolated HKRK peptide via Au-S bonds, these particles mediated cytosolic protein delivery by forming supramolecular complexes. ${ }^{[151]}$ The AuNPs were also used as components of self-assembled protein nanocapsules complexes, enhancing cytosolic protein delivery efficiency (Figure 12). ${ }^{[152]}$ Remarkably, these AuNPs-stabilized capsules do not promote cytosolic protein delivery by passing into the endosomes, but rather by direct fusion with the plasma membrane. Entrapping droplets of linoleic acid and decanoic acid within AuNPs-protein complexes generated a delivery system with enhanced efficiency, used for delivery of the pro-apoptotic caspase 3 in vitro, via direct plasma membrane fusion. ${ }^{[152]}$ The strength of the supramolecular interactions and respective roles of system constituents in increasing the overall efficiency was recently evaluated. ${ }^{[153]}$ Reducing the electrostatic interactions between the AuNPs and the fatty acid droplets favored cytosolic delivery of large proteins, such as the $120 \mathrm{kDa}$ dsRed or the $\beta$-galactosidase. Another successful example was where HKRK was replaced by arginine, permitting AuNPs-arginine assemblies to enhance the delivery of co-engineered proteins (caspase 9, E-tagged proteins) and enact genomic 
To link to this article (1) Chiper, M.; Niederreither, K.; Zuber, G. Transduction Methods for Cytosolic Delivery of Proteins and Bioconjugates Into Living Cells. Adv. Healthcare Mater. 2018, 7, e1701040.

Doi : $10.1002 /$ adhm. 201701040

editing. ${ }^{[154-155]}$ Furthermore, a co-delivery of pro-apoptotic caspase 3 along with paclitaxel treatment has reported successfully. ${ }^{[156]}$

\subsection{Nanocarriers and Near Infra Red Light}

Near infra red (NIR) light does not damage DNA like UV light does. It can penetrate tissues deeper than UV light, thus providing novel therapeutic opportunities and benefits. ${ }^{[157]}$ Single walled carbon nanotubes (SWNT) are nanomaterials that can be easily engulfed by mammalian cells in intracellular vesicles. They can also absorb NIR light and transform energy in heat. Heat might denature the conformation of proximal proteins and sometimes triggers the release of bound ligands. Chen et al. tested biotin-modified saponin or biotinmodified GFP release from streptavidin-grafted SWNT inside living cells upon NIR

irradiation. ${ }^{[158]}$ In HeLa cells, the SWNT-streptavidin/biotin-saponin conjugate assemblies promoted apoptosis of $20 \%$ of the cell population after light activation. A GFP fluorescence was also observed upon intravenous injection of GFP-loaded SWNT species into HeLa tumor bearing mice. Here, while fluorescence accumulation was observed into NIR light irradiated tumors, apoptosis efficiency remains low (e.g. only $20 \%$ of the saponin-treated cells underwent cell death). In any case, this report provides proof of feasibility of the aforementioned strategy.

Morales et al. prepared hollow AuNPs functionalized with protein via a photocleavable linker. ${ }^{[159]}$ This AuNPs-protein system allows regulated release of protein, since hollow AuNPs were designed to absorb NIR light, generating hot electrons that can cleave thiol-gold bonds. The AuNPs-protein system was incubated with cells that were then irradiated with a focused femtosecond pulsed-laser $(800 \mathrm{~nm})$. This allowed the release of 55\% of the recombinant-GFP from its carrier. Although the cells might be affected differently by 
To link to this article (1) Chiper, M.; Niederreither, K.; Zuber, G. Transduction Methods for Cytosolic Delivery of Proteins and Bioconjugates Into Living Cells. Adv. Healthcare Mater. 2018, 7, e1701040.

Doi : 10.1002/adhm.201701040

the use of NIR light, the delivery system could be finely tuned as a function of the cell line in order to avoid any thermal denaturation.

\subsection{Ultrasound Irradiation for Triggering Motion of Nanoparticles}

Low energy ultrasound (US) irradiation used for real-time medical imaging is considered to a harmless procedure. ${ }^{[160]}$ Improved instrumentation allows US energy manipulation at precise areas, promoting tissue vibrations and harmless local hyperthermia. Low energy ultrasound is effective in generating heat, an event that can be enhanced using sensitizers. ${ }^{[161]}$ EstebanFernandez de Avila et al. developed a gold nanowire carrier for US-assisted delivery of caspase 3 into tumor cells. ${ }^{[162]}$ Electrodeposition of gold nanorods on glass slides was employed. Then deposed gold nanorods were further coated with a biocompatible $\mathrm{pH}-$ responsive polymer (Eudragit ${ }^{\circledR}$ ) encapsulating caspase 3 . In total, this system was optimized for site-specific release in a gastric tumor environment. Upon carrier-tumor cell incubation, effective delivery occurred only in the presence of US, acting on the gold nanorods, propelling the carrier inside the cells where subsequently the polymer shell released caspase 3 upon $\mathrm{pH}$ modification. While both fast and efficient caspase 3 cytosolic delivery was observed, authors noted further improvement in transduction yield would improve in vivo effectiveness.

\subsection{Superparamagnetic Iron Oxide (SPIO) Nanoparticles and Magnetic Field}

Superparamagnetic nanoparticles (SPIO) are used as contrast agents for nuclear magnetic imaging (MRI), as well as in therapeutic approaches like hyperthermia and delivery by an external magnetic field. ${ }^{[163]}$ Several SPIO formulations have been approved by the U.S. Food and Drug Administration (FDA) for clinical use in MRI diagnostic. Strategies to use SPIOs to selectively and specifically deliver tumor-fighting drugs using an external magnetic field, 
applies the principle of magnetically controlling the movement of the carrier towards specific intracellular compartments. Proof-of principle of magnetic field-induced SPIO nanoparticle protein delivery involved $12 \mathrm{~nm}$ hydrophobic SPIO nanoparticles loaded into a polysaccharide nanogel able to entrap into its pores proteins such as BSA, $\beta$-galactosidase or caspase $3 .^{[164]}$ Cell apoptosis was observed only when a magnetic field was used, demonstrating cytosolic delivery of caspase 3 . Other magnetic protein carriers were produced by classical methods, either by covalent or non-covalent linking of polymers onto the surface of SPIO. ${ }^{[165]}$ These carriers transduced BSA and GFP inside the cytosol in a magnetic fielddependent manner. Nevertheless, the use of SPIO nanoparticles for large molecule transduction requires improved delivery efficiency, including strategies to reduce/avoid long term SPIO nanoparticles accumulation in animal, favoring biological elimination.

\subsection{Conclusions for this section}

Investigations indicate that nanoparticles containing inorganic elements such as gold or magnetic particles have potentially important, specific applications. These nanoparticlebased strategies adapt novel mechanisms of action to enhance delivery system efficiency.

\section{Overall Summary of Recent Findings and Future Perspectives}

Various novel technologies have been proposed to introduce exogenous proteins into living cells. These technologies can be classified in three main families according to their mode of action. The first family uses an independent source of energy to transiently create holes in the plasma membrane that are large enough to allow protein entry, but avoiding cell apoptosis. For routine protein transduction in cell cultures, electroporation is currently preferred because it offers reliable efficiency which can be combined with other in vitro approaches. ${ }^{[21]}$ A second methodology uses CPP conjugation to increase protein penetration 
To link to this article (1) Chiper, M.; Niederreither, K.; Zuber, G. Transduction Methods for Cytosolic Delivery of Proteins and Bioconjugates Into Living Cells. Adv. Healthcare Mater. 2018, 7, e1701040.

Doi : 10.1002/adhm.201701040

into the cells. Proteins can be incorporated into carriers within organic supramolecular complexes, or in presence of gold or SPIOs.

The CPP-proteins and various carrier formulations meet some criteria required for therapeutic applications and have been administrated in vivo in animal models of pathology, demonstrating feasibility. However, their efficiency remains too low for these techniques to be considered for immediate therapeutic applications. Hence, these approaches require refinement, notably to address what appears to be the main limitation - protein passage across the plasma membrane. To investigate this problem, in vitro cell culture models have frequently been combined with reporter protein assays (Table 2). Green fluorescent protein (GFP) or other fluorescent derivatives can be used, as these proteins are either commercially available or easily prepared. They serve to characterize and quantitate precise details of subcellular localization, hence quantitating overall protein content per cell. The GFPs, much like the $\beta$-galactosidase enzyme, do not allow a fine discrimination of subcellular localization after delivery. Senescent cells have also $\beta$-galactosidase activity. ${ }^{[166]}$ The Cre-recombinase is an interesting protein reporter because its cytosolic/nuclear localization in geneticallymodified organisms has a clear non-lethal action. The Cre-recombinase reporter system is also relatively sensitive, hence expression or amplification of the reporter gene might need a very low level of protein transduction. The commercially available pro-apoptotic Caspase 3 is also a popular choice for demonstrating that carriers can indeed convey at least part of their cargos into the cytosol. Like with the other proteins, inducing cell death (Cytochrome C, Saporin, RNAse A, Granzyme B), care should be taken to verify that the carrier/delivery method does not act together with the protein to kill the cell. In the Granzyme B case, it should be noted that this enzyme may also be active into extracellular spaces. ${ }^{[167]}$

A combination of transcription factors (Sox2, Oct4, cMyc, Klf4, Nanog) can reprogram differentiated cells such as skin fibroblasts to become induced pluripotent cells 
(iPS). These transcription factors have been employed as cargos, mostly to evaluate efficacy of CPP-based conjugates in cell reprogramming. Transduction of adequate quantities of iPSinducing proteins, along with alleviating the risk of viral protein transducing vectors are issues with classic techniques, with CPP-based strategies offering novel solutions to better manipulate stem cells and carry out cell reprogramming. ${ }^{[168]}$ Another category of clinically applicable targets for protein transduction are antibodies and their derivatives. To date, blocking monoclonal antibodies against DNA polymerase $\alpha$ and PCNA, have shown dramatically augmented delivery yield, with an unprecedented precision. For example, the cellular delivery of antibodies blocking DNA polymerase $\alpha(42,000$ molecules/cell) or PCNA (600,000 molecules/cell, adjustable to 40,000 using siRNA) can inhibit protein function by blocking protein anchorage, partially alleviating function. Full blockage, though, requires the quantity of antibodies per cell to match than of the protein target.

Sub-cellular compartmentalization may also preclude proper functioning of the cytosolic delivered proteins, especially if proteins have nuclear-specific activities. Free diffusion into the nucleus through the nuclear pores is possible, but is restricted to macromolecules with molecular masses below $60 \mathrm{kDa} \cdot{ }^{[169]}$ Passive entrapment of large $(>60$ $\mathrm{kDa}$ ) macromolecules into the nuclei occurs through mitosis, during which the nuclear compartment vanishes. Hence, for cell division independent nuclear import, critical in the case of proteins with exclusively nuclear activity, it is important to either respect a threshold limit (using $<60 \mathrm{kDa}$ proteins) or equip proteins with nuclear localization signal (NLS) to channel nuclear import using importin $\alpha / \beta$ machinery. These two approaches were used, specifically by digestion of the $150 \mathrm{kDa}$ IgG to a $50 \mathrm{kDa}$ Fab or by covalent conjugation of the Simian Virus 40 (SV40) large $\mathrm{T}$ antigen NLS peptide to full $150 \mathrm{kDa}$ IgG. Both approaches were productive. ${ }^{[18]}$ 
Nuclear accumulation of proteins can be improved and optimized using NLS extracted from other protein sources. The relative efficiency of NLS from the SV40 large T antigen (PKKKRKV), c-Myc (PAAKRVKLD), nucleoplasmin (AVKRPAATKKAGQAKKKKLD), and Tus protein (KLKIKRPVK) in promoting accumulation of NLS-GFP conjugates was compared in cultured cells lines using AuNPs. ${ }^{[170]}$ Results indicated important differences, with the c-Myc NLS-GFP displaying a nuclear accumulation intensity three times higher than the SV40 NLS-GFP. Instead of a NLS peptide, a synthetic molecule can be added for nuclear localization. Addition of a benzylboronate chemical motif allowed the $112 \mathrm{kDa}$ dsRED nuclear-excluded proteins to enter the nucleus using the importin $\alpha / \beta$ pathway. ${ }^{[171]}$

\section{Final Conclusions and Perspectives}

This report reviews recent advances in a variety of protein delivery methods. The conclusion is no unique single solution can be applied to all systems. Direct delivery of proteins into cultured cells is critical in the development of this technology. Several methods have been proposed for improved protein transduction, but none of these techniques fully satisfy all requirements needed for routine laboratory or future clinical applications. Clear advancements have occurred upon the commercialization of protein delivery reagents, yet because these commercial carriers are sensitive to variations in protein structure, their widespread applications for in vitro cell culture are somewhat limited. Currently use of electroporation, with the availability of a new generation of equipment, allowing precise selection of protein transduction conditions, currently makes electroporation the preferred choice for routine protein transduction in cell culture.

Advances in the transductions methods for the therapeutic introduction of proteins into whole mammalian organism have shown that a CPP-protein conjugates strategy is efficient, but requires further optimization. Carriers and non-covalent multifunctional formulations are 
now being developed for in vivo administration and offer versatility for addressing the complexity of a mammalian body and challenges with specific diseases. The key to developing this strategy is a better understanding on how to increase positive functions (such as improving transduction efficiency or controlling level) without destroying/modifying protein function or inducing unspecific toxicities. Improvements in targeting sites in a whole organism can include improved generalized application strategies (e.g. i.v. delivery combined with targeting peptides) or localized tumor administration. These are important clinical goals in targeted cancer therapy applications.

The key lesson is that intracellular protein delivery is at its beginning, clearly meriting innovative ideas. The potential for advancement in this field is tremendous, as libraries of antibodies and derivatives exist for protein targeting and even more are under development. The wide availability of many recombinant proteins, both in terms of sufficient quality and quantity will help in this initiative. The long-term potential is to combine novel techniques for cytosolic protein transduction with individualized therapeutic potential, uniting biotechnological research and investment to produce therapeutic advancements in complex diseases

\section{Acknowledgements}

This report was supported by the grant ANR-10-LABX-0026_CSC.

Received: ((will be filled in by the editorial staff))

Revised: ((will be filled in by the editorial staff)) Published online: ((will be filled in by the editorial staff))

\section{References}

[1] M. Uhlen, L. Fagerberg, B. M. Hallstrom, C. Lindskog, P. Oksvold, A. Mardinoglu, A. Sivertsson, C. Kampf, E. Sjostedt, A. Asplund, I. Olsson, K. Edlund, E. Lundberg, S. Navani, C. A.-K. Szigyarto, J. Odeberg, D. Djureinovic, J. O. Takanen, S. Hober, T. Alm, P.-H. 
To link to this article (1) Chiper, M.; Niederreither, K.; Zuber, G. Transduction Methods for Cytosolic Delivery of Proteins and Bioconjugates Into Living Cells. Adv. Healthcare Mater. 2018, 7, e1701040.

Doi : 10.1002/adhm.201701040

Edqvist, H. Berling, H. Tegel, J. Mulder, J. Rockberg, P. Nilsson, J. M. Schwenk, M. Hamsten, K. von Feilitzen, M. Forsberg, L. Persson, F. Johansson, M. Zwahlen, G. von Heijne, J. Nielsen, F. Ponten, Science 2015, 347, 1260419.

[2] B. Schwanhäusser, D. Busse, N. Li, G. Dittmar, J. Schuchhardt, J. Wolf, W. Chen, M. Selbach, Nature 2011, 473, 337.

[3] P. Zhang, E. Wagner, Top. Curr. Chem. 2017, 375.

[4] A. L. J. Marschall, S. Dübel, Comput. Struct. Biotechnol. J. 2016, 14, 304.

[5] A. L. Marschall, S. Dübel, T. Böldicke, $m A b s$ 2015, 7, 1010.

[6] Z. Gu, A. Biswas, M. Zhao, Y. Tang, Chem. Soc. Rev. 2011, 40, 3638.

[7] Y. Lu, W. Sun, Z. Gu, J. Controlled Release 2014, 194, 1.

[8] A. Fu, R. Tang, J. Hardie, M. E. Farkas, V. M. Rotello, Bioconjug. Chem. 2014, 25, 1602.

[9] M. Ray, Y.-W. Lee, F. Scaletti, R. Yu, V. M. Rotello, Nanomed. 2017, 12, 941.

[10] A. L. J. Marschall, A. Frenzel, T. Schirrmann, M. Schüngel, S. Dubel, mAbs 2011, 3, 3.

[11] R. Todorova, Drug Deliv. 2011, 18, 586.

[12] I. König, A. Zarrine-Afsar, M. Aznauryan, A. Soranno, B. Wunderlich, F. Dingfelder, J. C. Stüber, A. Plückthun, D. Nettels, B. Schuler, Nat. Methods 2015, 12, 773.

[13] K. Luby-Phelps, Int. Rev. Cytol. 2000, 192, 189.

[14] A. Blangy, H. A. Lane, P. d'Hérin, M. Harper, M. Kress, E. A. Nigg, Cell 1995, 83, 1159.

[15] S. D. Laufer, T. Restle, Curr. Pharm. Des. 2008, 14, 3637.

[16] M. L. Yarmush, A. Golberg, G. Serša, T. Kotnik, D. Miklavčič, Annu. Rev. Biomed. Eng. 2014, 16, 295.

[17] S. Baron, J. Poast, D. Rizzo, E. McFarland, E. Kieff, J. Immunol. Methods 2000, 242, 115.

[18] G. Freund, A.-P. Sibler, D. Desplancq, M. Oulad-Abdelghani, M. Vigneron, J. Gannon, M. H. Van Regenmortel, E. Weiss, $m A b s$ 2013, 5, 518.

[19] D. Desplancq, G. Freund, S. Conic, A.-P. Sibler, P. Didier, A. Stoessel, M. OuladAbdelghani, M. Vigneron, J. Wagner, Y. Mély, B. Chatton, L. Tora, E. Weiss, Exp. Cell Res. 2016, 342, 145.

[20] S. Pinel, E. Aman, F. Erblang, J. Dietrich, B. Frisch, J. Sirman, A. Kichler, A.-P. Sibler, M. Dontenwill, F. Schaffner, G. Zuber, J. Controlled Release 2014, $182,1$.

[21] A. L. Marschall, C. Zhang, A. Frenzel, T. Schirrmann, M. Hust, F. Perez, S. Dübel, $m A b s \mathbf{2 0 1 4}, 6,943$.

[22] S.-H. Lee, S. N. Danishmalik, J.-I. Sin, Hum. Vaccines Immunother. 2015, 11, 1889.

[23] S. Sloot, O. M. Rashid, A. A. Sarnaik, J. S. Zager, Cancer Control J. Moffitt Cancer Cent. 2016, 23, 12.

[24] L. Lambricht, A. Lopes, S. Kos, G. Sersa, V. Préat, G. Vandermeulen, Expert Opin. Drug Deliv. 2016, 13, 295.

[25] M. Tsukakoshi, S. Kurata, Y. Nomiya, Y. Ikawa, T. Kasuya, Appl. Phys. B Photophysics Laser Chem. 1984, 35, 135.

[26] A. Vogel, J. Noack, G. Hüttman, G. Paltauf, Appl. Phys. B 2005, 81, 1015.

[27] Y.-C. Wu, T.-H. Wu, D. L. Clemens, B.-Y. Lee, X. Wen, M. A. Horwitz, M. A. Teitell, P.-Y. Chiou, Nat. Methods 2015, 12, 439.

[28] J. L. Sandell, T. C. Zhu, J. Biophotonics 2011, 4, 773.

[29] A. Sharei, J. Zoldan, A. Adamo, W. Y. Sim, E. Jackson, S. Mao, S. Schneider, M.-J. Han, A. Lytton-Jean, P. A. Basto, S. Jhunjhunwala, J. Lee, D. A. Heller, J. W. Kang, G. C. Hartoularos, K.-S. Kim, D. G. Anderson, R. Langer, K. F. Jensen, Proc. Natl. Acad. Sci. U. S. A. 2013, 110, 2082.

[30] X. Han, Z. Liu, M. c. Jo, K. Zhang, Y. Li, Z. Zeng, N. Li, Y. Zu, L. Qin, Sci. Adv. 
To link to this article (1) Chiper, M.; Niederreither, K.; Zuber, G. Transduction Methods for Cytosolic Delivery of Proteins and Bioconjugates Into Living Cells. Adv. Healthcare Mater. 2018, 7, e1701040.

Doi : 10.1002/adhm.201701040

2015, 1 , e1500454.

[31] D. S. D’Astolfo, R. J. Pagliero, A. Pras, W. R. Karthaus, H. Clevers, V. Prasad, R. J. Lebbink, H. Rehmann, N. Geijsen, Cell 2015, 161, 674.

[32] I. Walev, S. C. Bhakdi, F. Hofmann, N. Djonder, A. Valeva, K. Aktories, S. Bhakdi, Proc. Natl. Acad. Sci. 2001, 98, 3185.

[33] S. E. Stewart, S. C. Kondos, A. Y. Matthews, M. E. D’Angelo, M. A. Dunstone, J. C. Whisstock, J. A. Trapani, P. I. Bird, J. Biol. Chem. 2014, 289, 9172.

[34] S. Fawell, J. Seery, Y. Daikh, C. Moore, L. L. Chen, B. Pepinsky, J. Barsoum, Proc. Natl. Acad. Sci. 1994, 91, 664.

[35] A. Falanga, M. Galdiero, S. Galdiero, Int. J. Mol. Sci. 2015, 16, 25323.

[36] T. Takeuchi, S. Futaki, Chem. Pharm. Bull. (Tokyo) 2016, 64, 1431.

[37] S. Bashyal, G. Noh, T. Keum, Y. W. Choi, S. Lee, J. Pharm. Investig. 2016, 46, 205.

[38] H. Nagahara, A. M. Vocero-Akbani, E. L. Snyder, A. Ho, D. G. Latham, N. A. Lissy, M. Becker-Hapak, S. A. Ezhevsky, S. F. Dowdy, Nat. Med. 1998, 4, 1449.

[39] R. Marchione, L. Liguori, D. Laurin, J.-L. Lenormand, J. Mol. Biochem. 2016, 5, 51.

[40] S. R. Schwarze, A. Ho, A. Vocero-Akbani, S. F. Dowdy, Science 1999, 285, 1569.

[41] J. S. Wadia, R. V. Stan, S. F. Dowdy, Nat. Med. 2004, 10, 310.

[42] S. Asoh, I. Ohsawa, T. Mori, K. -i. Katsura, T. Hiraide, Y. Katayama, M. Kimura, D. Ozaki, K. Yamagata, S. Ohta, Proc. Natl. Acad. Sci. 2002, 99, 17107.

[43] Y. D. Kwon, S. K. Oh, H. S. Kim, S.-Y. Ku, S. H. Kim, Y. M. Choi, S. Y. Moon, Mol. Ther. 2005, 12, 28.

[44] C. Pan, B. Lu, H. Chen, C. E. Bishop, Mol. Biol. Rep. 2010, 37, 2117.

[45] H. Zhang, Y. Ma, J. Gu, B. Liao, J. Li, J. Wong, Y. Jin, Biomaterials 2012, 33, 5047.

[46] D. Kim, C. Jeon, J. Kim, M. Kim, C. Yoon, I. Choi, S. Kim, Y. Bae, Exp. Cell Res.

2006, 312, 1277.

[47] S. Huang, D. Liu, J. Zeng, Y. Yuan, Q. Xiao, C. Sun, C. Li, K. Tao, J. Wen, Z. Huang, W. Feng, Protein Expr. Purif. 2009, 68, 167.

[48] J. Jo, S. Hong, W. Y. Choi, D. R. Lee, Sci. Rep. 2015, 4.

[49] H. Zhou, S. Wu, J. Y. Joo, S. Zhu, D. W. Han, T. Lin, S. Trauger, G. Bien, S. Yao, Y. Zhu, G. Siuzdak, H. R. Schöler, L. Duan, S. Ding, Cell Stem Cell 2009, 4, 381.

[50] C. Avignolo, L. Bagnasco, B. Biasotti, A. Melchiori, V. Tomati, I. Bauer, A. Salis, L. Chiossone, M. C. Mingari, P. Orecchia, B. Carnemolla, D. Neri, L. Zardi, S. Parodi, FASEB J. 2007, 22, 1237.

[51] O. Poungpair, A. Pootong, S. Maneewatch, P. Srimanote, P. Tongtawe, T. Songserm, P. Tapchaisri, W. Chaicumpa, Bioconjug. Chem. 2010, 21, 1134.

[52] Y. Zhang, J. Wang, J. Tang, L. Guo, J. Yang, Y. Huang, Y. Tan, S. Fu, X. Kong, F. Zheng, Mol. Cells 2009, 27, 159.

[53] G.-Q. Huang, J.-N. Wang, J.-M. Tang, L. Zhang, F. Zheng, J.-Y. Yang, L.-Y. Guo, X. Kong, Y.-Z. Huang, Y. Liu, S.-Y. Chen, J. Transl. Med. 2011, 9, 73.

[54] B. Caulier, L. Berthoin, H. Coradin, F. Garban, M. C. Dagher, B. Polack, B. Toussaint, J. L. Lenormand, D. Laurin, Int. J. Pharm. 2017, 529, 65.

[55] H. Wang, J. Ma, Y. Yang, F. Zeng, C. Liu, Bioconjug. Chem. 2016, 27, 1373.

[56] J. J. Cronican, D. B. Thompson, K. T. Beier, B. R. McNaughton, C. L. Cepko, D. R. Liu, ACS Chem. Biol. 2010, 5, 747.

[57] D.-K. Choi, J. Bae, S.-M. Shin, J.-Y. Shin, S. Kim, Y.-S. Kim, mAbs 2014, 6, 1402.

[58] J. Kim, D.-K. Choi, S. Park, S.-M. Shin, J. Bae, D.-M. Kim, T. H. Yoo, Y.-S. Kim, Biochem. Biophys. Res. Commun. 2015, 467, 771.

[59] V. J. Bruce, M. Lopez-Islas, B. R. McNaughton, Protein Sci. 2016, 25, 1129.

[60] T. Li, M. Vandesquille, F. Koukouli, C. Dudeffant, I. Youssef, P. Lenormand, C. Ganneau, U. Maskos, C. Czech, F. Grueninger, C. Duyckaerts, M. Dhenain, S. Bay, B. 
To link to this article (1) Chiper, M.; Niederreither, K.; Zuber, G. Transduction Methods for Cytosolic Delivery of Proteins and Bioconjugates Into Living Cells. Adv. Healthcare Mater. 2018, 7, e1701040.

Doi : 10.1002/adhm.201701040

Delatour, P. Lafaye, J. Controlled Release 2016, 243, 1.

[61] F. Duchardt, M. Fotin-Mleczek, H. Schwarz, R. Fischer, R. Brock, Traffic 2007, 8, 848.

[62] N. J. Caron, S. P. Quenneville, J. P. Tremblay, Biochem. Biophys. Res. Commun. 2004, $319,12$.

[63] G. Cao, W. Pei, H. Ge, Q. Liang, Y. Luo, F. R. Sharp, A. Lu, R. Ran, S. H. Graham, J. Chen, J. Neurosci. Off. J. Soc. Neurosci. 2002, 22, 5423.

[64] R. M. Mentzer, J. Wider, C. N. Perry, R. A. Gottlieb, J. Cardiovasc. Pharmacol. Ther. 2014, 19, 315 .

[65] K. Sudo, K. Niikura, K. Iwaki, S. Kohyama, K. Fujiwara, N. Doi, J. Controlled Release 2017, 255, 1.

[66] M. Li, Y. Tao, Y. Shu, J. R. LaRochelle, A. Steinauer, D. Thompson, A. Schepartz, Z.-Y. Chen, D. R. Liu, J. Am. Chem. Soc. 2015, 137, 14084.

[67] J. E. Dixon, G. Osman, G. E. Morris, H. Markides, M. Rotherham, Z. Bayoussef, A. J. El Haj, C. Denning, K. M. Shakesheff, Proc. Natl. Acad. Sci. 2016, 113, E291.

[68] E. Koren, A. Apte, R. R. Sawant, J. Grunwald, V. P. Torchilin, Drug Deliv. 2011, 18, 377.

[69] O. Boussif, F. Lezoualc'h, M. A. Zanta, M. D. Mergny, D. Scherman, B. Demeneix, J. P. Behr, Proc. Natl. Acad. Sci. U. S. A. 1995, 92, 7297.

[70] G. Zuber, E. Dauty, M. Nothisen, P. Belguise, J. P. Behr, Adv. Drug Deliv. Rev. 2001, $52,245$.

[71] S. Bersani, S. Salmaso, F. Mastrotto, E. Ravazzolo, A. Semenzato, P. Caliceti, Bioconjug. Chem. 2012, 23, 1415.

[72] N. Zhang, Z. Yan, X. Zhao, Q. Chen, M. Ma, ACS Appl. Mater. Interfaces 2016, 8, 25725.

[73] K. Maier, E. Wagner, J. Am. Chem. Soc. 2012, 134, 10169.

[74] X. Liu, P. Zhang, D. He, W. Rödl, T. Preiß, J. O. Rädler, E. Wagner, U. Lächelt, Biomacromolecules 2016, 17, 173.

[75] K. Maier, I. Martin, E. Wagner, Mol. Pharm. 2012, 9, 3560.

[76] P. Zhang, D. He, P. M. Klein, X. Liu, R. Röder, M. Döblinger, E. Wagner, Adv. Funct. Mater. 2015, 25, 6627.

[77] Y.-M. Go, D. P. Jones, Biochim. Biophys. Acta BBA - Gen. Subj. 2008, 1780, 1273.

[78] J. Liu, T. Gaj, J. T. Patterson, S. J. Sirk, C. F. Barbas III, PLoS ONE 2014, 9, e85755.

[79] Z. Qian, J. R. LaRochelle, B. Jiang, W. Lian, R. L. Hard, N. G. Selner, R.

Luechapanichkul, A. M. Barrios, D. Pei, Biochemistry (Mosc.) 2014, 53, 4034.

[80] J. Yin, A. J. Lin, D. E. Golan, C. T. Walsh, Nat. Protoc. 2006, 1, 280.

[81] N. Nischan, H. D. Herce, F. Natale, N. Bohlke, N. Budisa, M. C. Cardoso, C. P. R. Hackenberger, Angew. Chem. Int. Ed. 2015, 54, 1950.

[82] P. Lonn, A. D. Kacsinta, X.-S. Cui, A. S. Hamil, M. Kaulich, K. Gogoi, S. F. Dowdy, Sci. Rep. 2016, 6, 32301.

[83] A. Chauhan, A. Tikoo, A. K. Kapur, M. Singh, J. Controlled Release 2007, 117, 148.

[84] G. Guidotti, L. Brambilla, D. Rossi, Trends Pharmacol. Sci. 2017, 38, 406.

[85] D. Dalkara, G. Zuber, J.-P. Behr, Mol. Ther. 2004, 9, 964.

[86] O. Zelphati, Y. Wang, S. Kitada, J. C. Reed, P. L. Felgner, J. Corbeil, J. Biol. Chem. 2001, 276, 35103.

[87] B. T. F. van der Gun, A. Monami, S. Laarmann, T. Raskó, K. Ślaska-Kiss, E. Weinhold, R. Wasserkort, L. F. M. H. de Leij, M. H. J. Ruiters, A. Kiss, P. M. J. McLaughlin, J. Controlled Release 2007, 123, 228.

[88] D. Dalkara, C. Chandrashekhar, G. Zuber, J. Controlled Release 2006, 116, 353.

[89] M. Furuhata, H. Kawakami, K. Toma, Y. Hattori, Y. Maitani, Bioconjug. Chem. 2006, 
To link to this article (1) Chiper, M.; Niederreither, K.; Zuber, G. Transduction Methods for Cytosolic Delivery of Proteins and Bioconjugates Into Living Cells. Adv. Healthcare Mater. 2018, 7, e1701040.

Doi : 10.1002/adhm.201701040

$17,935$.

[90] S. R. Sarker, R. Hokama, S. Takeoka, Mol. Pharm. 2014, 11, 164.

[91] Y. Yamada, S. M. V. Perez, M. Tabata, J. Abe, Y. Yasuzaki, H. Harashima, J. Pharm. Sci. 2015, 104, 2845.

[92] S. A. Altınoğlu, M. Wang, K. Q. Li, Y. Li, Q. Xu, Biomater Sci 2016, 4, 1773.

[93] M. Wang, J. A. Zuris, F. Meng, H. Rees, S. Sun, P. Deng, Y. Han, X. Gao, D. Pouli, Q.

Wu, I. Georgakoudi, D. R. Liu, Q. Xu, Proc. Natl. Acad. Sci. 2016, 113, 2868.

[94] D. Ye, D. Xu, A. U. Singer, R. L. Juliano, Pharm. Res. 2002, 19, 1302.

[95] C. O. Weill, S. Biri, A. Adib, P. Erbacher, Cytotechnology 2008, 56, 41.

[96] J. Courtete, A.-P. Sibler, G. Zeder-Lutz, D. Dalkara, M. Oulad-Abdelghani, G. Zuber, E. Weiss, Mol. Cancer Ther. 2007, 6, 1728.

[97] S. M. Tugizov, R. Herrera, P. Veluppillai, D. Greenspan, V. Soros, W. C. Greene, J. A. Levy, J. M. Palefsky, Virology 2011, 409, 211.

[98] K. Nakahira, J. A. Haspel, V. A. K. Rathinam, S.-J. Lee, T. Dolinay, H. C. Lam, J. A. Englert, M. Rabinovitch, M. Cernadas, H. P. Kim, K. A. Fitzgerald, S. W. Ryter, A. M. K. Choi, Nat. Immunol. 2011, 12, 222.

[99] K. Yamaguchi, M. Inoue, N. Goshima, J. Biomed. Biotechnol. 2011, 2011, 1.

[100] B. Zassler, I. E. Blasig, C. Humpel, J. Neurooncol. 2005, 71, 127.

[101] I. Orlov, A. Schertel, G. Zuber, B. Klaholz, R. Drillien, E. Weiss, P. Schultz, D. Spehner, Sci. Rep. 2015, 5.

[102] M. Khan, K. Narayanan, H. Lu, Y. Choo, C. Du, N. Wiradharma, Y.-Y. Yang, A. C. A. Wan, Biomaterials 2013, 34, 5336.

[103] G. Creusat, G. Zuber, ChemBioChem 2008, 9, 2787.

[104] M. Chiper, N. Tounsi, R. Kole, A. Kichler, G. Zuber, J. Controlled Release 2017, 246, 60.

[105] J. B. Gossart, E. Pascal, F. Meyer, E. Heuillard, M. Gonçalves, F. Gossé, E. Robinet, B. Frisch, C. Seguin, G. Zuber, Glob. Chall. 2017, 1, 1700013.

[106] V. Postupalenko, A.-P. Sibler, D. Desplancq, Y. Nominé, D. Spehner, P. Schultz, E. Weiss, G. Zuber, J. Controlled Release 2014, 178, 86.

[107] H. Sun, F. Meng, R. Cheng, C. Deng, Z. Zhong, Acta Biomater. 2014, 10, 2159.

[108] M. C. Morris, J. Depollier, J. Mery, F. Heitz, G. Divita, Nat. Biotechnol. 2001, 19, 1173.

[109] L. Kurzawa, M. Pellerano, M. C. Morris, Biochim. Biophys. Acta BBA - Biomembr.

2010, 1798, 2274.

[110] K. Aoshiba, N. Yokohori, A. Nagai, Am. J. Respir. Cell Mol. Biol. 2003, 28, 555.

[111] M. B. Maron, AJP Lung Cell. Mol. Physiol. 2005, 289, L349.

[112] E. Kondo, M. Seto, K. Yoshikawa, T. Yoshino, Mol. Cancer Ther. 2004, 3, 1623.

[113] E. Kondo, T. Tanaka, T. Miyake, T. Ichikawa, M. Hirai, M. Adachi, K. Yoshikawa, K. Ichimura, N. Ohara, A. Moriwaki, I. Date, R. Ueda, T. Yoshino, Mol. Cancer Ther. 2008, 7, 1461 .

[114] T. B. Stoilova, S. I. Kovalchuk, N. S. Egorova, A. Y. Surovoy, V. T. Ivanov, Biochim. Biophys. Acta BBA - Biomembr. 2008, 1778, 2026.

[115] C. Wu, S. L. Lo, J. Boulaire, M. L. W. Hong, H. M. Beh, D. S. Y. Leung, S. Wang, J. Controlled Release 2008, 130, 140.

[116] H. Chang, J. Lv, X. Gao, X. Wang, H. Wang, H. Chen, X. He, L. Li, Y. Cheng, Nano Lett. 2017, 17, 1678.

[117] A. Ö. Tezgel, P. Jacobs, C. M. Backlund, J. C. Telfer, G. N. Tew, Biomacromolecules 2017, 18, 819 .

[118] F. Sgolastra, C. M. Backlund, E. Ilker Ozay, B. M. deRonde, L. M. Minter, G. N. Tew, J. Controlled Release 2017, 254, 131. 
To link to this article (1) Chiper, M.; Niederreither, K.; Zuber, G. Transduction Methods for Cytosolic Delivery of Proteins and Bioconjugates Into Living Cells. Adv. Healthcare Mater. 2018, 7, e1701040.

Doi : 10.1002/adhm.201701040

[119] J. A. Zuris, D. B. Thompson, Y. Shu, J. P. Guilinger, J. L. Bessen, J. H. Hu, M. L. Maeder, J. K. Joung, Z.-Y. Chen, D. R. Liu, Nat. Biotechnol. 2014, 33, 73.

[120] A. A. Eltoukhy, D. Chen, O. Veiseh, J. M. Pelet, H. Yin, Y. Dong, D. G. Anderson, Biomaterials 2014, 35, 6454.

[121] X. Wang, Y. Li, Q. Li, C. I. Neufeld, D. Pouli, S. Sun, L. Yang, P. Deng, M. Wang, I. Georgakoudi, S. Tang, Q. Xu, J. Controlled Release 2017.

[122] Y. Lee, T. Ishii, H. J. Kim, N. Nishiyama, Y. Hayakawa, K. Itaka, K. Kataoka, Angew. Chem. Int. Ed. 2010, 49, 2552.

[123] Y. Lee, T. Ishii, H. J. Kim, N. Nishiyama, Y. Hayakawa, K. Itaka, K. Kataoka, Angew. Chem. 2010, 122, 2606.

[124] V. Postupalenko, D. Desplancq, I. Orlov, Y. Arntz, D. Spehner, Y. Mely, B. P.

Klaholz, P. Schultz, E. Weiss, G. Zuber, Angew. Chem. Int. Ed. 2015, 54, 10583.

[125] P. Zhang, B. Steinborn, U. Lächelt, S. Zahler, E. Wagner, Biomacromolecules 2017.

[126] C. Chittimalla, L. Zammut-Italiano, G. Zuber, J.-P. Behr, J. Am. Chem. Soc. 2005, 127, 11436.

[127] E. Wagner, Acc. Chem. Res. 2012, 45, 1005.

[128] R. Röder, J. Helma, T. Preiß, J. O. Rädler, H. Leonhardt, E. Wagner, Pharm. Res.

2017, 34, 161.

[129] M. Yan, J. Du, Z. Gu, M. Liang, Y. Hu, W. Zhang, S. Priceman, L. Wu, Z. H. Zhou, Z. Liu, T. Segura, Y. Tang, Y. Lu, Nat. Nanotechnol. 2010, 5, 48.

[130] M. Zhao, Y. Liu, R. S. Hsieh, N. Wang, W. Tai, K.-I. Joo, P. Wang, Z. Gu, Y. Tang, J. Am. Chem. Soc. 2014, 136, 15319.

[131] M. Zhao, B. Hu, Z. Gu, K.-I. Joo, P. Wang, Y. Tang, Nano Today 2013, 8, 11.

[132] A. Biswas, Y. Liu, T. Liu, G. Fan, Y. Tang, Biomaterials 2012, 33, 5459.

[133] Z. Gu, M. Yan, B. Hu, K.-I. Joo, A. Biswas, Y. Huang, Y. Lu, P. Wang, Y. Tang, Nano Lett. 2009, 9, 4533.

[134] J. Chen, Y. Zou, C. Deng, F. Meng, J. Zhang, Z. Zhong, Chem. Mater. 2016, 28, 8792.

[135] G. Mattheolabakis, L. Milane, A. Singh, M. M. Amiji, J. Drug Target. 2015, 23, 605.

[136] J. Chen, J. Ouyang, Q. Chen, C. Deng, F. Meng, J. Zhang, R. Cheng, Q. Lan, Z. Zhong, ACS Appl. Mater. Interfaces 2017.

[137] D. Ha, N. Yang, V. Nadithe, Acta Pharm. Sin. B 2016, 6, 287.

[138] A. V. Vlassov, S. Magdaleno, R. Setterquist, R. Conrad, Biochim. Biophys. Acta BBA Gen. Subj. 2012, $1820,940$.

[139] N. Yim, S.-W. Ryu, K. Choi, K. R. Lee, S. Lee, H. Choi, J. Kim, M. R. Shaker, W.

Sun, J.-H. Park, D. Kim, W. Do Heo, C. Choi, Nat. Commun. 2016, 7, 12277.

[140] A. Erazo-Oliveras, K. Najjar, L. Dayani, T.-Y. Wang, G. A. Johnson, J.-P. Pellois, Nat. Methods 2014, 11, 861.

[141] K. Najjar, A. Erazo-Oliveras, J.-P. Pellois, J. Vis. Exp. 2015.

[142] A. Erazo-Oliveras, K. Najjar, D. Truong, T.-Y. Wang, D. J. Brock, A. R. Prater, J.-P. Pellois, Cell Chem. Biol. 2016, 23, 598.

[143] M. Akishiba, T. Takeuchi, Y. Kawaguchi, K. Sakamoto, H.-H. Yu, I. Nakase, T.

Takatani-Nakase, F. Madani, A. Gräslund, S. Futaki, Nat. Chem. 2017.

[144] J. Zhang, M. C. Shin, A. E. David, J. Zhou, K. Lee, H. He, V. C. Yang, Mol. Pharm.

2013, 10, 3892.

[145] H.-Y. Chiu, W. Deng, H. Engelke, J. Helma, H. Leonhardt, T. Bein, Sci. Rep. 2016, 6.

[146] Y. Niu, M. Yu, J. Zhang, Y. Yang, C. Xu, M. Yeh, E. Taran, J. J. C. Hou, P. P. Gray,

C. Yu, J Mater Chem B 2015, 3, 8477.

[147] X. Wu, S. Wu, L. Yang, J. Han, S. Han, J. Mater. Chem. 2012, 22, 17121.

[148] J.-H. Yeom, M. Joo, B. Lee, K. P. Kim, N.-C. Ha, Y. Park, J. Bae, K. Lee, J. Ind. Eng. Chem. Amst. Neth. 2017, 45, 5. 
To link to this article (1) Chiper, M.; Niederreither, K.; Zuber, G. Transduction Methods for Cytosolic Delivery of Proteins and Bioconjugates Into Living Cells. Adv. Healthcare Mater. 2018, 7, e1701040.

Doi : 10.1002/adhm.201701040

[149] S.-M. Ryou, J.-H. Yeom, H. J. Kang, M. Won, J.-S. Kim, B. Lee, M.-J. Seong, N.-C. Ha, J. Bae, K. Lee, J. Controlled Release 2014, 196, 287.

[150] C. Alric, I. Miladi, D. Kryza, J. Taleb, F. Lux, R. Bazzi, C. Billotey, M. Janier, P. Perriat, S. Roux, O. Tillement, Nanoscale 2013, 5, 5930.

[151] P. Ghosh, X. Yang, R. Arvizo, Z.-J. Zhu, S. S. Agasti, Z. Mo, V. M. Rotello, J. Am. Chem. Soc. 2010, 132, 2642.

[152] R. Tang, C. S. Kim, D. J. Solfiell, S. Rana, R. Mout, E. M. Velázquez-Delgado, A. Chompoosor, Y. Jeong, B. Yan, Z.-J. Zhu, C. Kim, J. A. Hardy, V. M. Rotello, ACS Nano 2013, 7, 6667.

[153] R. Tang, Z. Jiang, M. Ray, S. Hou, V. M. Rotello, Nanoscale 2016, 8, 18038.

[154] R. Mout, M. Ray, G. Yesilbag Tonga, Y.-W. Lee, T. Tay, K. Sasaki, V. M. Rotello, ACS Nano 2017, 11, 2452.

[155] R. Mout, M. Ray, T. Tay, K. Sasaki, G. Yesilbag Tonga, V. M. Rotello, ACS Nano 2017, 11, 6416.

[156] C. S. Kim, R. Mout, Y. Zhao, Y.-C. Yeh, R. Tang, Y. Jeong, B. Duncan, J. A. Hardy, V. M. Rotello, Bioconjug. Chem. 2015, 26, 950.

[157] T. Henderson, Neural Regen. Res. 2016, 11, 563.

[158] H. Li, X. Fan, X. Chen, ACS Appl. Mater. Interfaces 2016, 8, 4500.

[159] D. P. Morales, G. B. Braun, A. Pallaoro, R. Chen, X. Huang, J. A. Zasadzinski, N. O. Reich, Mol. Pharm. 2015, 12, 600.

[160] G. A. Husseini, W. G. Pitt, A. M. Martins, Colloids Surf. B Biointerfaces 2014, 123, 364.

[161] H. Shibaguchi, H. Tsuru, M. Kuroki, M. Kuroki, Anticancer Res. 2011, 31, 2425.

[162] B. Esteban-Fernández de Ávila, D. E. Ramírez-Herrera, S. Campuzano, P.

Angsantikul, L. Zhang, J. Wang, ACS Nano 2017.

[163] Y.-X. J. Wang, S. M. Hussain, G. P. Krestin, Eur. Radiol. 2001, 11, 2319.

[164] R. Kawasaki, Y. Sasaki, K. Katagiri, S. Mukai, S. Sawada, K. Akiyoshi, Angew. Chem. Int. Ed. 2016, 55, 11377.

[165] Z. Wang, J. Zhang, R. Li, J. Chen, J. Appl. Polym. Sci. 2014, 131, n/a.

[166] D. J. Kurz, S. Decary, Y. Hong, J. D. Erusalimsky, J. Cell Sci. 2000, 113 ( Pt 20), 3613.

[167] W. A. Boivin, D. M. Cooper, P. R. Hiebert, D. J. Granville, Lab. Invest. 2009, 89, 1195 .

[168] H. Liu, F. Zeng, M. Zhang, F. Huang, J. Wang, J. Guo, C. Liu, H. Wang, J. Controlled Release 2016, 226, 124.

[169] C. Dingwall, R. A. Laskey, Annu. Rev. Cell Biol. 1986, 2, 367.

[170] M. Ray, R. Tang, Z. Jiang, V. M. Rotello, Bioconjug. Chem. 2015, 26, 1004.

[171] R. Tang, M. Wang, M. Ray, Y. Jiang, Z. Jiang, Q. Xu, V. M. Rotello, J. Am. Chem. Soc. 2017.

[172] C. Rudolph, G. Adam, A. Simm, Anal. Biochem. 1999, 269, 66.

[173] G. F. Morris, M. B. Mathews, J. Biol. Chem. 1989, 264, 13856. 
To link to this article (1) Chiper, M.; Niederreither, K.; Zuber, G. Transduction Methods for Cytosolic Delivery of Proteins and Bioconjugates Into Living Cells. Adv. Healthcare Mater. 2018, 7, e1701040.

Doi : 10.1002/adhm.201701040

Figures and Captions 
To link to this article (1) Chiper, M.; Niederreither, K.; Zuber, G. Transduction Methods for Cytosolic Delivery of Proteins and Bioconjugates Into Living Cells. Adv. Healthcare Mater. 2018, 7, e1701040.

Doi : 10.1002/adhm.201701040

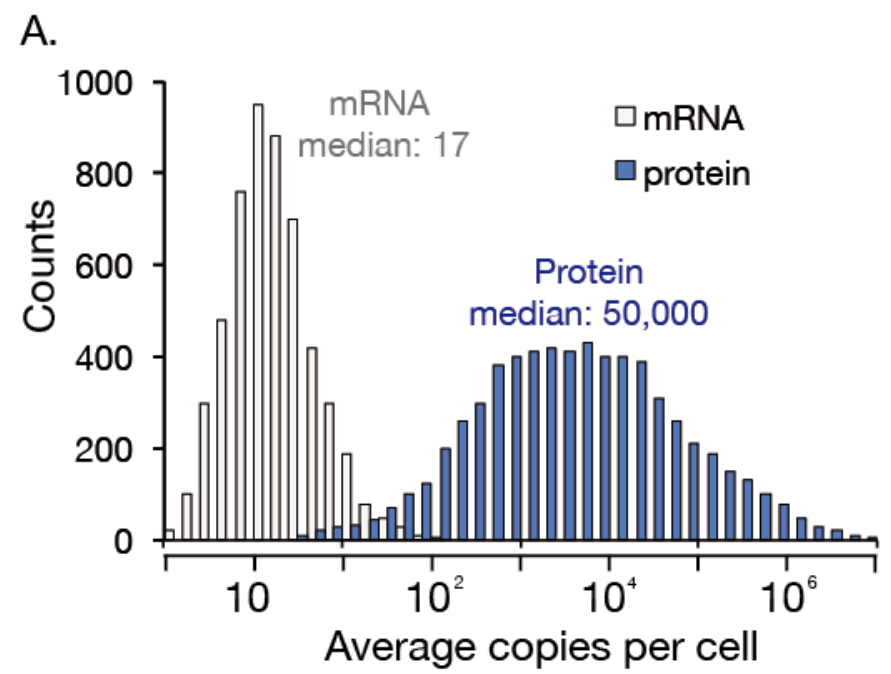

B.

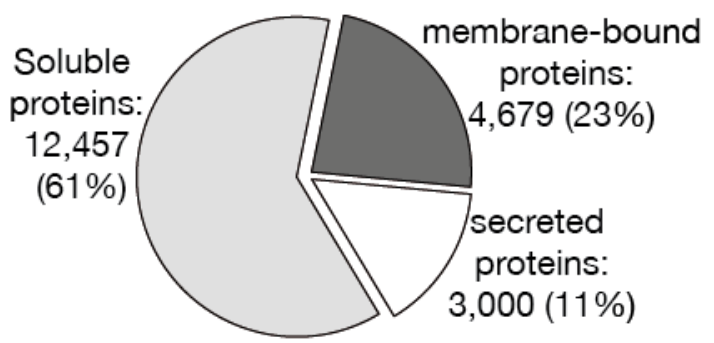

Figure 1. A. Global levels of mRNAs and proteins in mammalian cells. Data adapted from. ${ }^{[2]}$ B. Prediction and analysis of genes according to their solubility, membrane-anchorage properties, and extracellular localization. Data are from. ${ }^{[1]}$ Soluble proteins are assumed to remain within the cell. 

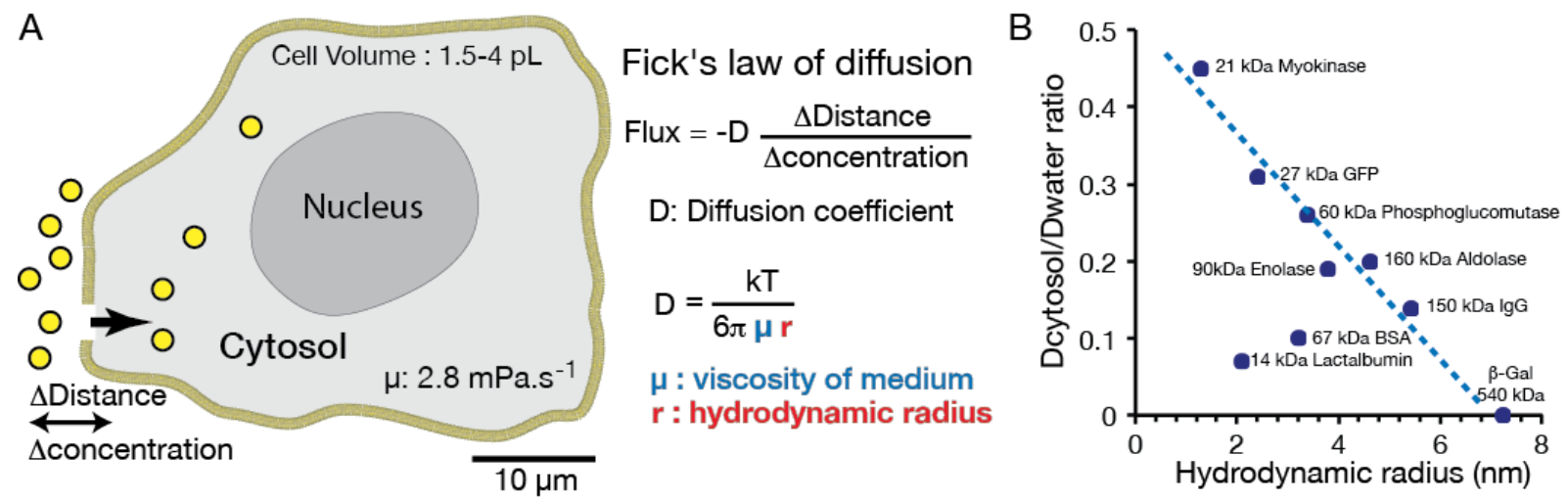

Figure 2. A. Definition of Fick's law of diffusion and its implication for the diminished diffusion of proteins with increased molecular weights into the cytosol. In the equation linking the diffusion coefficient (D) to the viscosity $(\mu)$ and hydrodynamic radius $(r), k$ is the Boltzmann constant and $\mathrm{T}$ is the temperature. B. Data reporting the relation between the cytosolic/water diffusion ratio and protein molecular weight are extracted from LubyPhelps. ${ }^{[13]}$

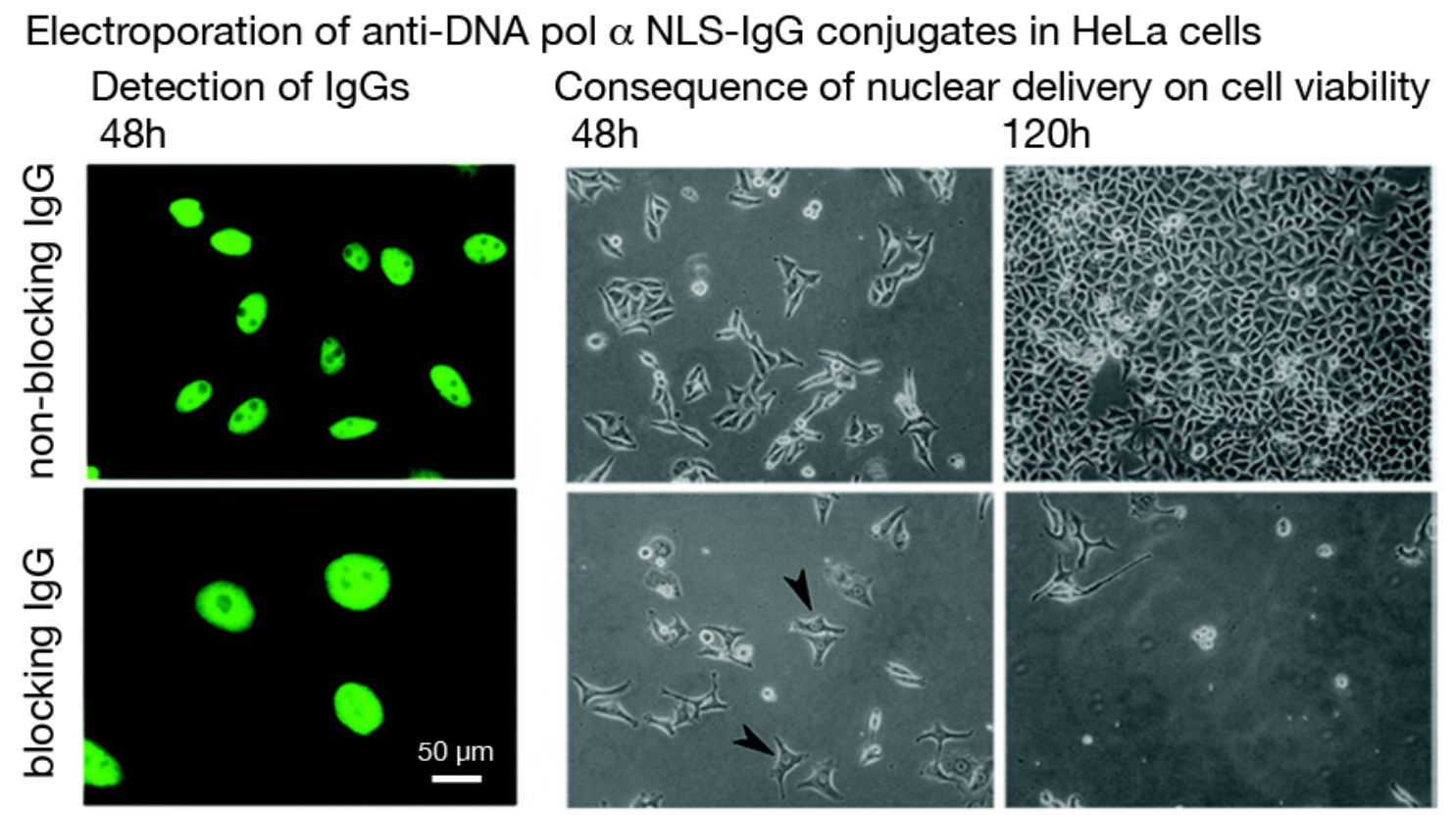

Figure 3. Electroporation of mouse monoclonal antibodies targeting the DNA polymerase (pol) $\alpha$ in HeLa cells. The two antibodies were equipped with a nuclear localization signal (NLS) peptide and delivered into HeLa cells by electroporation. Immunofluorescence analysis (left images, visualization of the antibodies in green) shows both antibodies to accumulate in the cell nuclei. The blocking of an anti-DNA pol $\alpha$ NLS-IgG conjugate led to a dramatic increase in cell nucleus volume and to cell death, whereas the non-blocking conjugate was apparently inert. Data obtained with permission. ${ }^{[18]}$ 


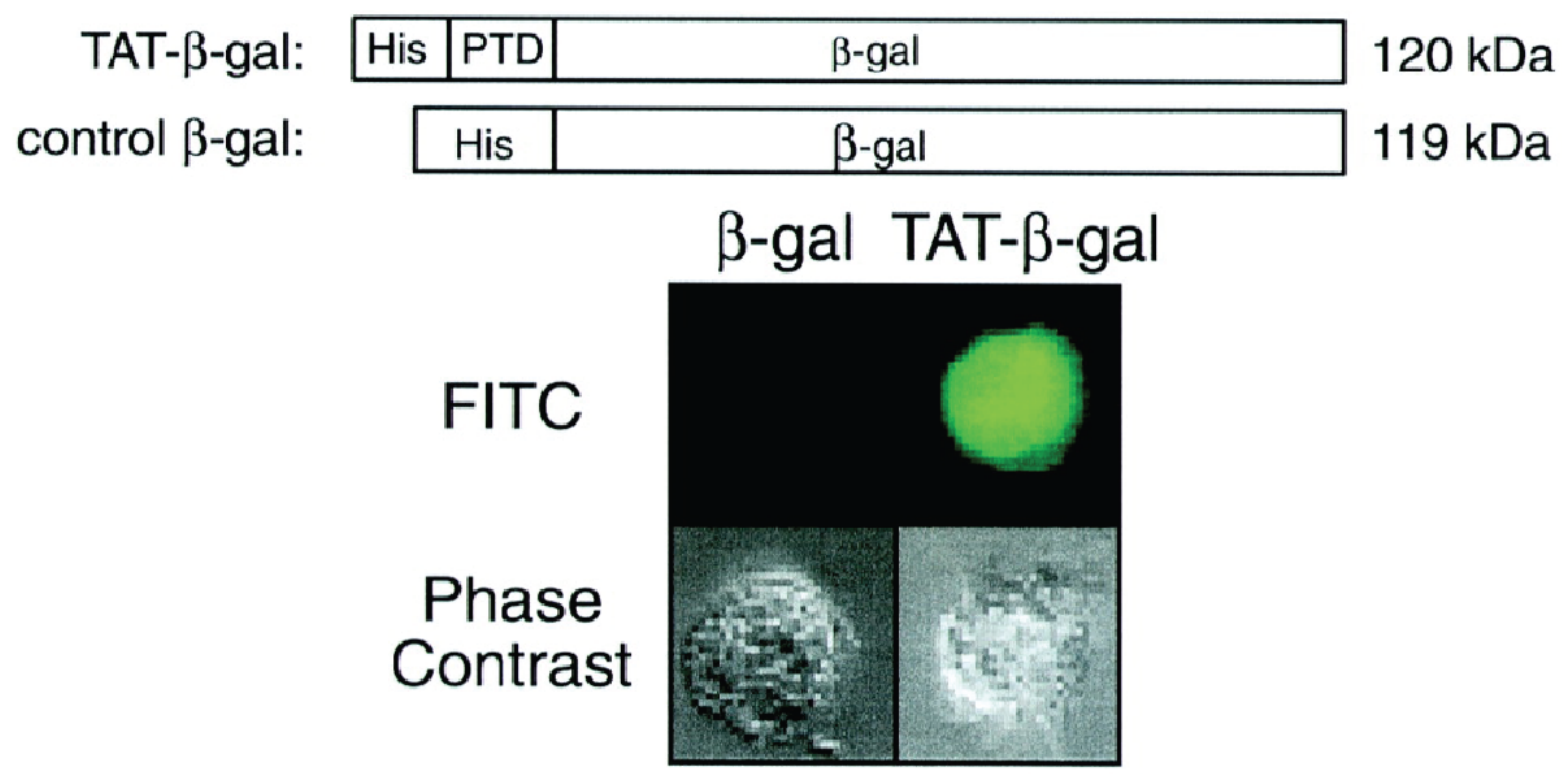

Figure 4. Schematic illustration of TAT- $\beta-G a l$ and $\beta-G a l$ fusion constructs and microscopy images of Jurkat T cells after incubation of the living cells with fluorescently labeled $\beta$-Gal and TAT- $\beta-G a l$ fusion proteins. Reproduced with permission. ${ }^{[40]}$ 
To link to this article (1) Chiper, M.; Niederreither, K.; Zuber, G. Transduction Methods for Cytosolic Delivery of Proteins and Bioconjugates Into Living Cells. Adv. Healthcare Mater. 2018, 7, e1701040.

Doi : 10.1002/adhm.201701040

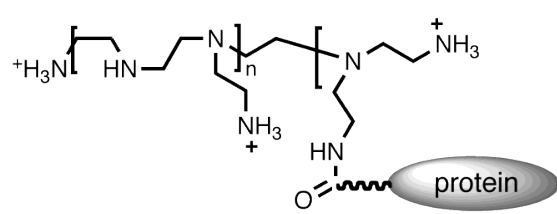

PEI-protein conjugate<smiles>NC(=[NH2+])NCCCCCCCNC(=O)CCNc1nc(N(CCCCCCCNC(N)=[NH2+])CCCCCCNC(N)=[NH2+])nc(N(CCCCCCNC(N)=[NH2+])CCCCCCNC(N)=[NH2+])n1</smiles>

tetra-Guanidinium-containing derivative-protein conjugate<smiles>N=C(N)NCCC[C@@H]1NC(=O)[C@H](CCCNC(=N)N)NC(=O)[C@H](Cc2ccc3ccccc3c2)NC(=O)[C@H](Cc2ccccc2)NC(=O)[C@@H](CCCNC(=N)N)NC(=O)[C@H](CCCNC(=N)N)NC(=O)[C@H](CCCNC(=N)N)NC1=O</smiles>

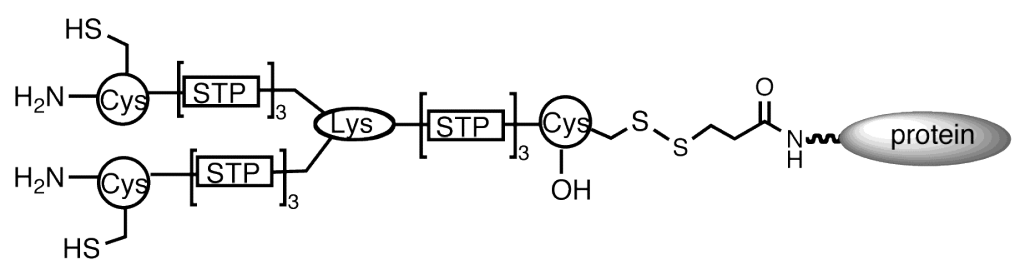

thiol/disulfide-contained cationic oligomer-protein conjugate

Figure 5. Examples of chemical covalent transcription conjugations increasing protein entry. 


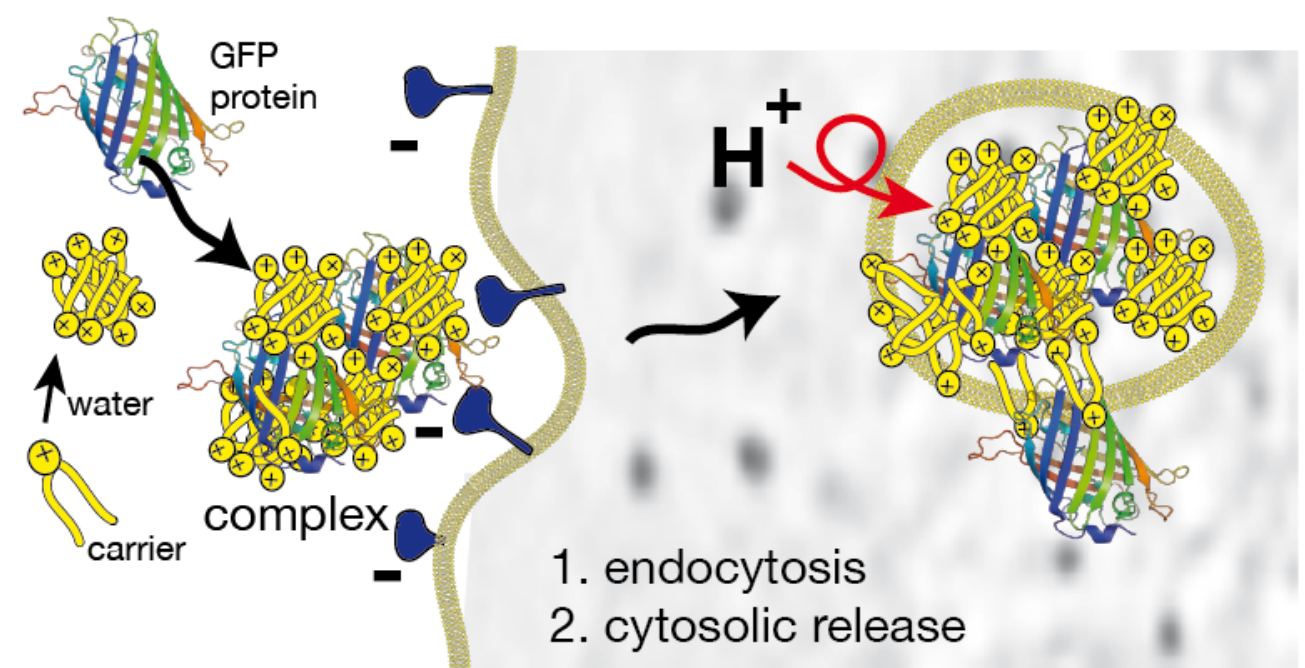

Figure 6. Illustration of the associative approach for cytosolic delivery of protein. The protein (here the green fluorescent protein (GFP)) associates with several carriers, and produces a nanometric-sub-micrometric supramolecular complex. The complex binds to cell surface receptors and is engulfed into the endocytic compartment. Rupture of the bilayer occurs, which then liberates a portion of the protein into the cytosol. 
To link to this article (1) Chiper, M.; Niederreither, K.; Zuber, G. Transduction Methods for Cytosolic Delivery of Proteins and Bioconjugates Into Living Cells. Adv. Healthcare Mater. 2018, 7, e1701040.

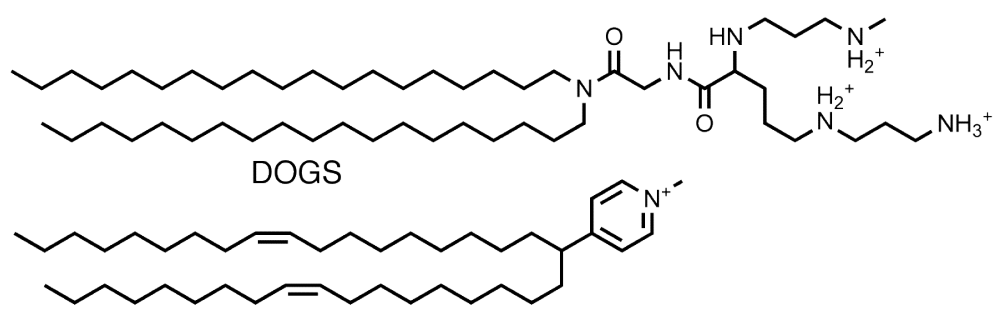

SAINT-2<smiles>CCCCCCCCC=CCCCCCCCCCCCCCCCC(=O)OCC(COP(=O)([O-])OCC[NH3+])OC(=O)CCCCCCCCCCC</smiles>

1,2-Dioleoyl-phosphatidylethanlolamine (DOPE)

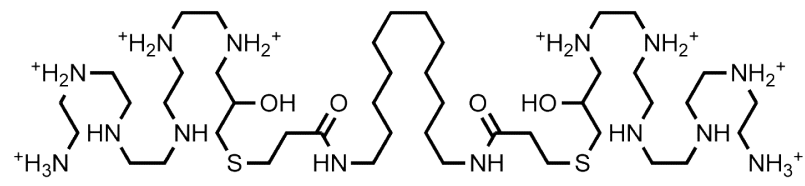

Cationic bola-amphiphile

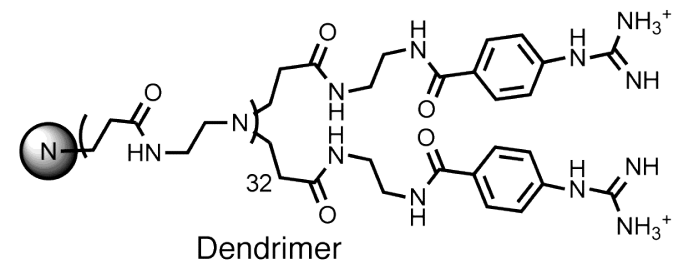<smiles>CC(C)(C)CCNCCNC(=S)Nc1cccnc1</smiles><smiles>C=C(C)C1OC(C(=O)OCCNC(N)N)C(C(=O)OC)C1C(=O)OCCNC(N)N</smiles>

Polymer ( $\pi-\mathrm{PEI})$ oxanorbornene-based Oligomers

Figure 7. Chemical structures of selected carriers known to improve protein delivery. 
A



Hoechst 33342
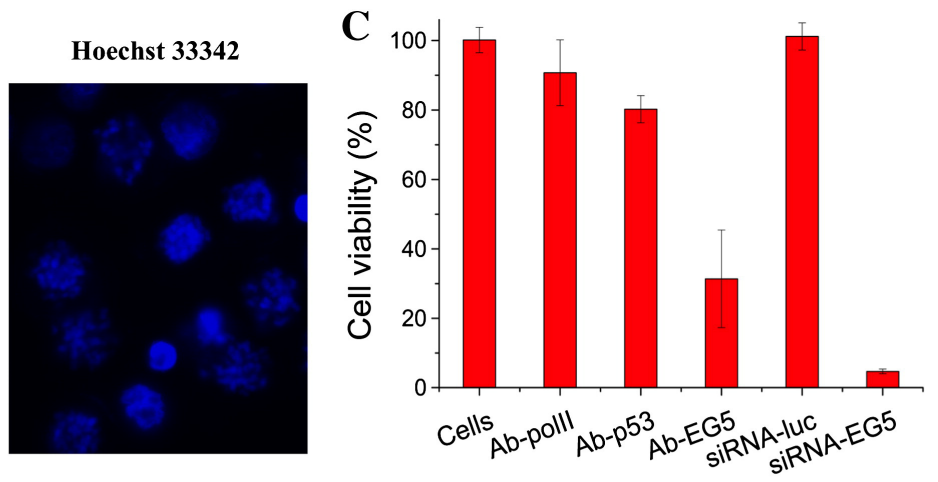

B

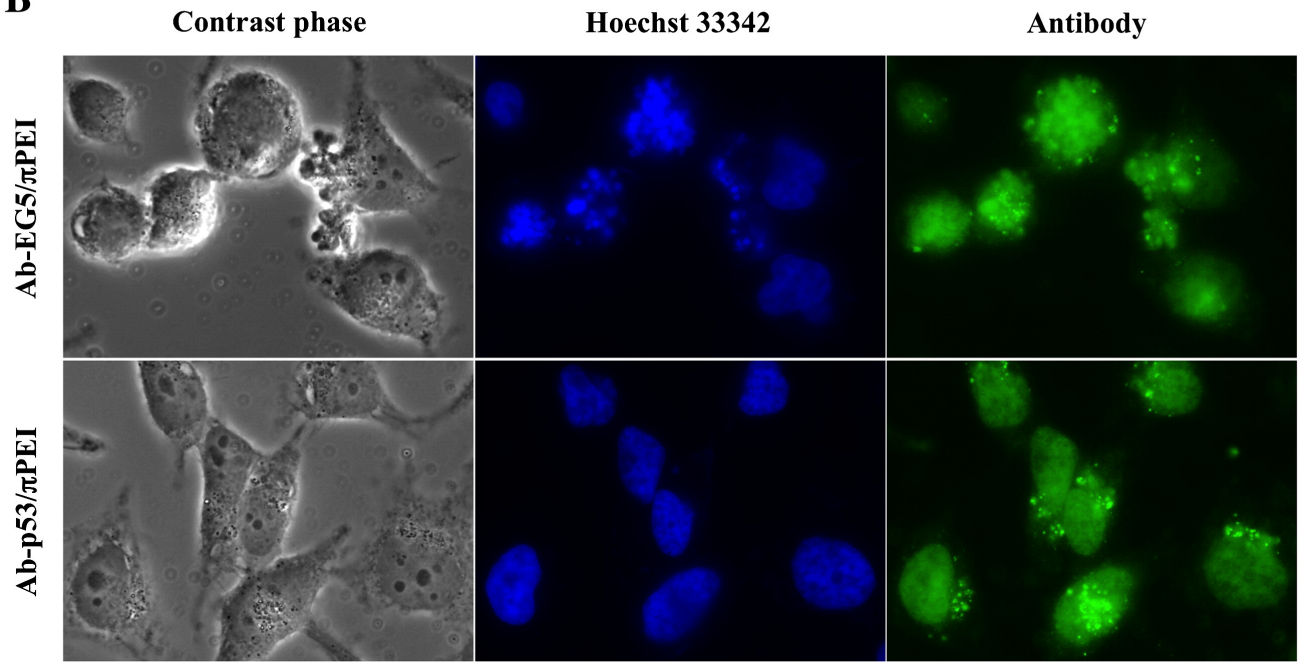

Figure 8. Effect of $\pi$ PEI-mediated delivery of $10 \mathrm{nM}$ siRNA-EG5 (A), anti-EG5 and anti-p53 (control) antibodies (B) into HeLa cells. Cells were fixed and analyzed after $48 \mathrm{~h}$ incubation. The cellular DNA was stained with Hoechst 33342 and the $\pi$ PEI-delivered Ab (green channel) were immunodetected. (C) Evaluation of cell viability following incubation in the presence of the indicated polyplexes. Viability was measured using the MTT assay. Reproduced with permission. ${ }^{.106]}$ 


\section{A. Direct protein anionization}

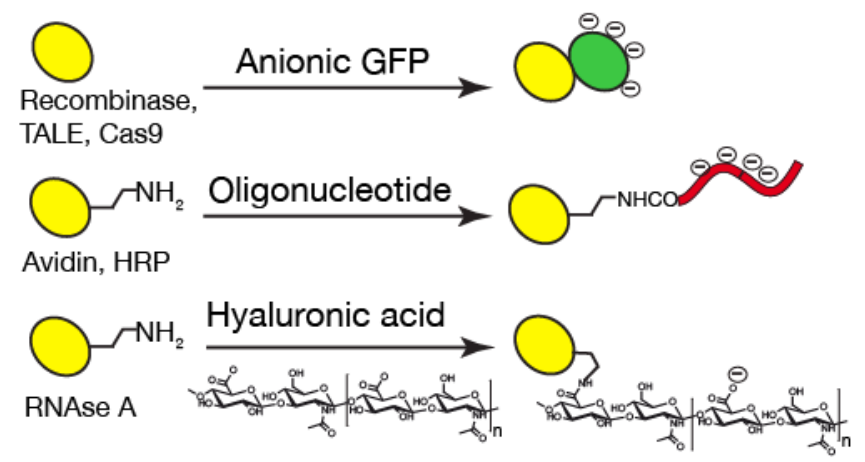

\section{B. Acid-reversible protein anionization}

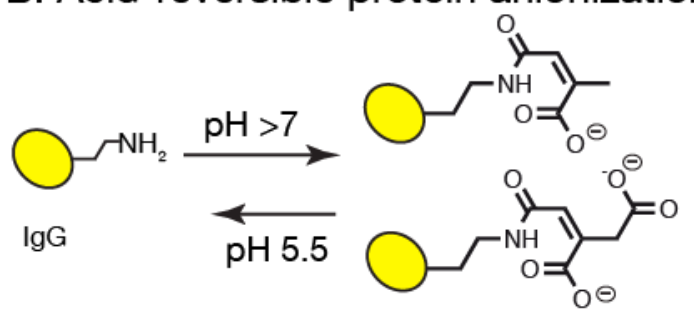

C. Acid-reversible affinity binding on anionic polymer

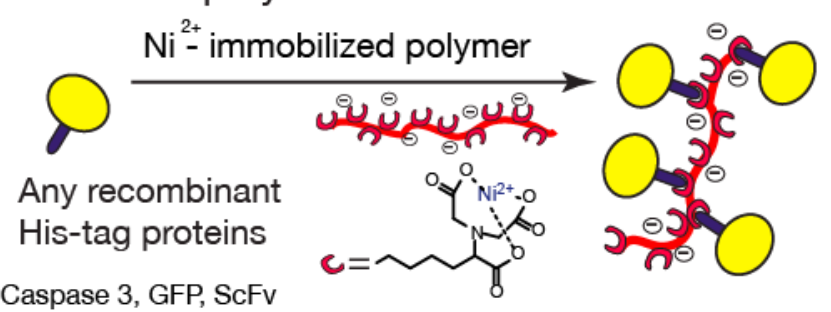

Figure 9. Illustration of methods facilitating protein/carrier assembly formation. A. Proteins are equipped with polyanionic domain to an anionic protein, an oligonucleotide, or to hyaluronic acid. The anionic GFP is then fused following biological engineering approaches. The two other molecules can be conjugated by a synthetic chemical strategy. B. The anionic charge of the protein can be transiently increased by modification of the lysine's residues of protein into $\mathrm{pH}$ sensitive groups. C. His-tagged recombinant protein is affinity immobilized onto an anionic template. 
A. In situ co-polymerization

期 ${ }_{\mathrm{NH}_{2}}$ Neutral monomer

$\mathrm{Y}_{\text {Positively charged monomer }}^{\mathrm{O}}$<smiles>C=CC=CC(=O)OCC</smiles>

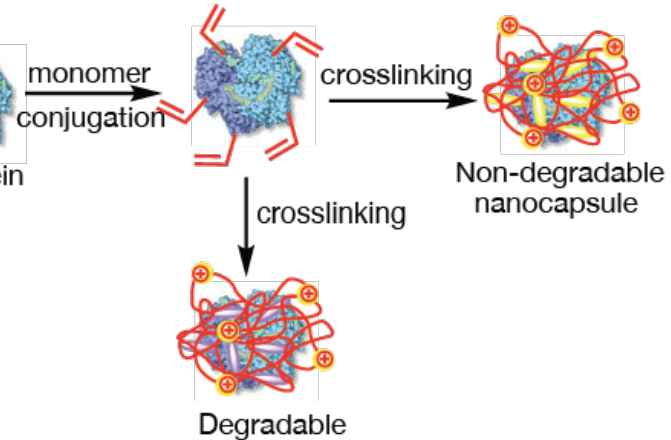

Degradable crosslinker

Degradable nanocapsule

B. Protein encapsulation and equipment with tissue targeting-ligands

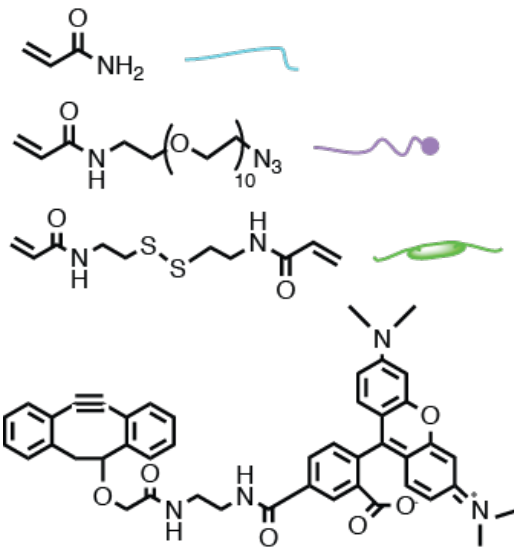

Neutral, clickable and redox-sensitive monomers

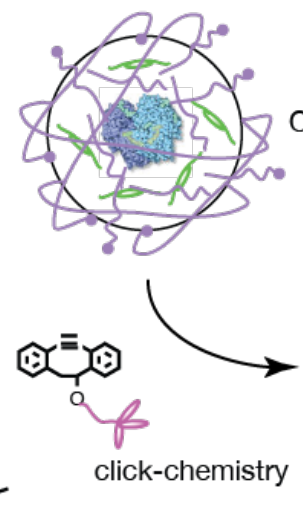
nanocapsules

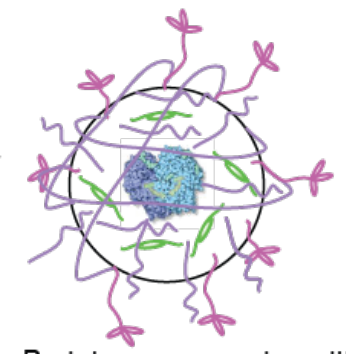

Protein nanocapsules with cancer-targeting ligands

C. Photo-click crosslinking
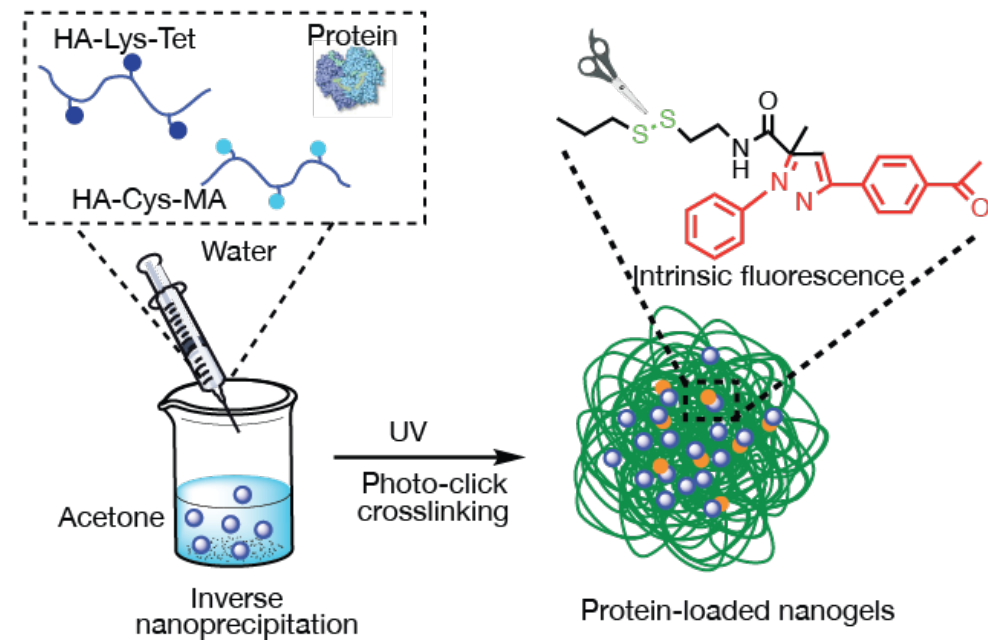

Protein-loaded nanogels

Figure 10. Schematic strategies for protein encapsulation. A. Degradable and non-degradable single protein nanocapsules were generated by monomer conjugation on the surface of protein followed by in situ co-polymerization B. Active targeting protein nanocapsules are obtained by combining polymerization and click chemistry methods. C. Protein encapsulated nanogel can be obtained by inverse nanoprecipitation followed by photo-click crosslinking. 


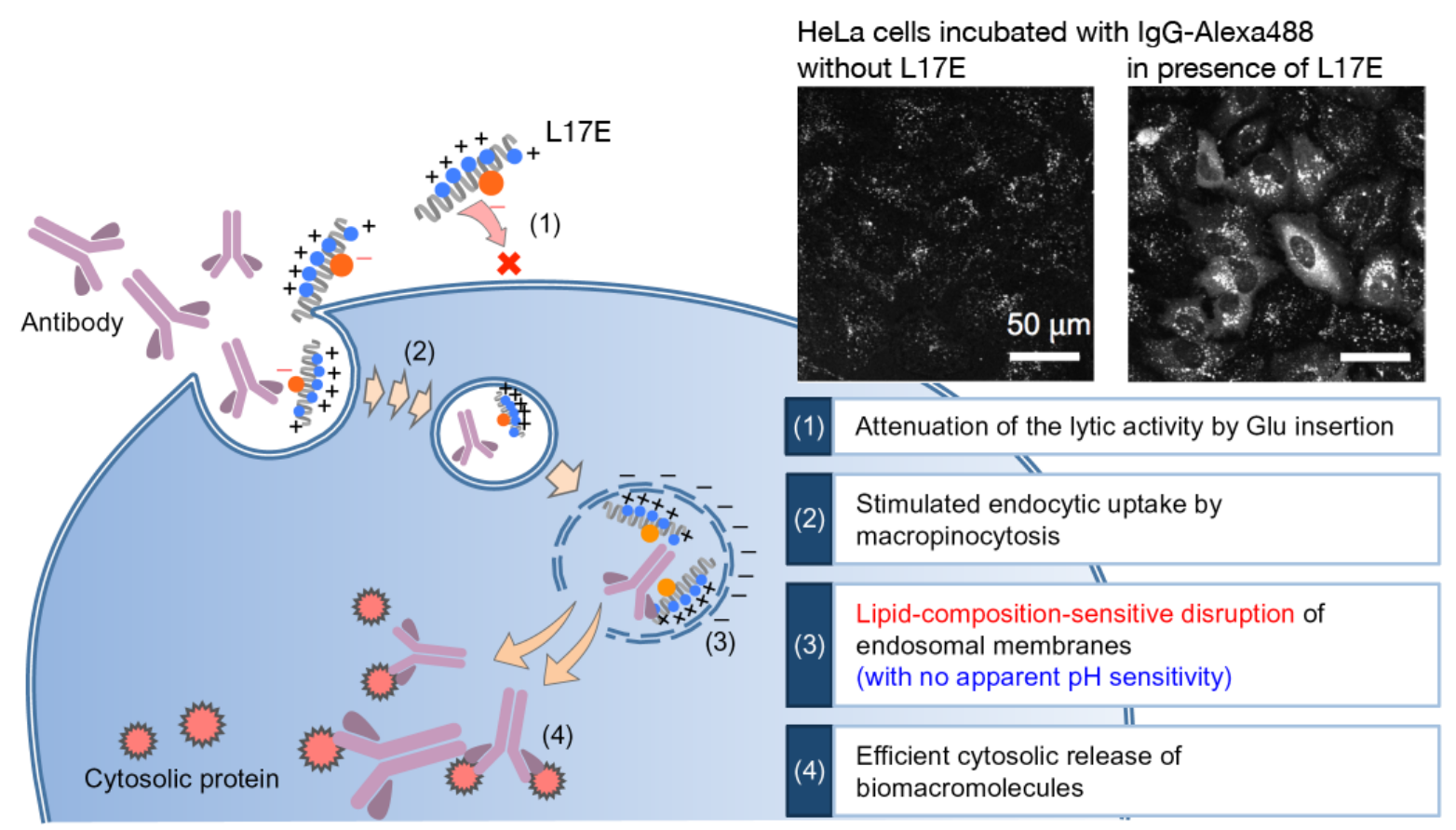

Figure 11. Proposed mechanism of action of the L17E peptide during intracellular antibody delivery. Images on the upper right side: HeLa cells were treated with a fluorescently labeled polyclonal antibody with or without the presence of L17E in the medium. Adapted with permission. ${ }^{[143]}$ 

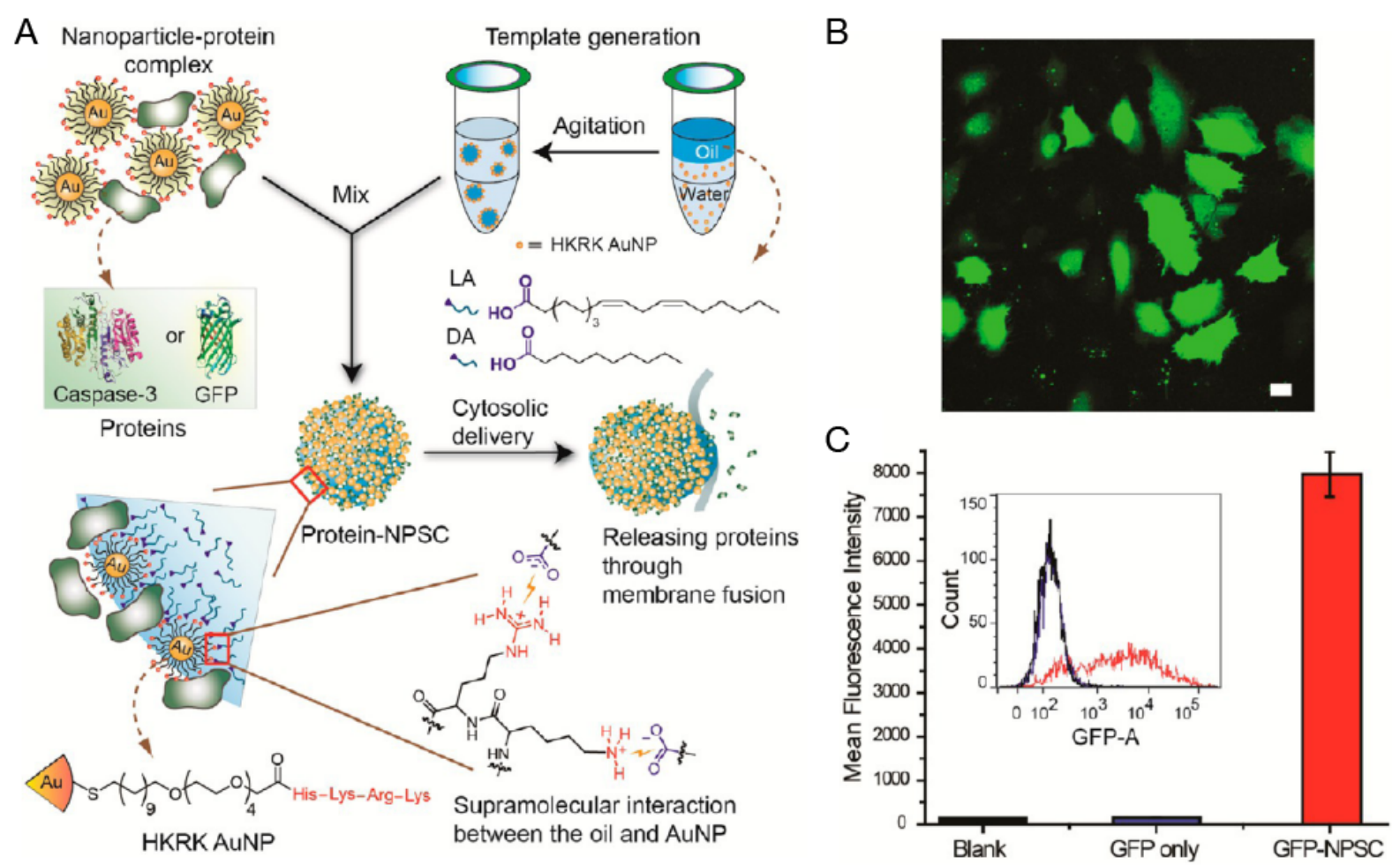

Figure 12. A. Schematic illustration of the preparation of the gold nanoparticle-stabilized nanocapsules (NPSCs) incorporating proteins. B. Image showing GFP delivery into HeLa cells by NPSCs. C. Flow cytometry results of HeLa cells treated for $2 \mathrm{~h}$ with GFP-NPSCs (red), GFP alone (blue) or untreated (black). Scale bar: $20 \mu \mathrm{m}$. Adapted with permission. ${ }^{[152]}$ 
To link to this article (1) Chiper, M.; Niederreither, K.; Zuber, G. Transduction Methods for Cytosolic Delivery of Proteins and Bioconjugates Into Living Cells. Adv. Healthcare Mater. 2018, 7, e1701040.

Doi : 10.1002/adhm.201701040

Table 1. Biotechnological engineering of transduction domain-protein chimera

\begin{tabular}{|c|c|c|c|c|}
\hline $\begin{array}{l}\text { Transduction } \\
\text { domain }^{\text {a) }}\end{array}$ & $\begin{array}{l}\text { Protein } \\
\text { cargo }\end{array}$ & $\begin{array}{l}\text { Experimental } \\
\text { model }\end{array}$ & $\begin{array}{l}\text { Application/ } \\
\text { outcome }\end{array}$ & Reference \\
\hline $\begin{array}{l}\text { TAT: } \\
\text { YGRKKRRQRRR }\end{array}$ & $\begin{array}{c}\mathrm{P} 27^{\mathrm{kip} 1} \mathrm{Cdk} \\
\text { inhibitor protein }\end{array}$ & Jurkat T cells, HepG $2^{\text {b) }}$ & Research tool & [38] \\
\hline YGRKKRRQRRR & $\beta$-galactosidase & C57BL/6 mice & $\begin{array}{l}\text { Distribution } \\
\text { analysis }\end{array}$ & [40] \\
\hline YGRKKRRQRRR & $\begin{array}{l}35 \mathrm{kDa} \text { Cre } \\
\text { recombinase }\end{array}$ & tex.loxP.EG T cells & $\begin{array}{c}\text { Proof of } \\
\text { transduction }^{\text {a) }}\end{array}$ & [41] \\
\hline YGRKKRRQRRR & $\begin{array}{l}\text { Bcl-XL variant } \\
\quad(\text { FNK) }\end{array}$ & Gerbils i.p. & $\begin{array}{l}\text { Ischemia brain } \\
\text { injury }\end{array}$ & [42] \\
\hline YGRKKRRQRRR & $\begin{array}{l}\text { Sox2, Oct4, } \\
\text { cMyc Klf4, } \\
\text { Nanog }\end{array}$ & $\begin{array}{l}\text { HFF cells, HeLa, } \\
\text { fibroblasts }\end{array}$ & $\begin{array}{l}\text { Stem cell } \\
\text { reprogrammation }\end{array}$ & {$[45]$} \\
\hline YGRKKRRQRRR & PDX1 & Embryonic stem cells & $\begin{array}{c}\text { Stem cell } \\
\text { reprogrammation }\end{array}$ & {$[43]$} \\
\hline $\begin{array}{l}\text { Cytoplasmic TD } \\
\text { YGRRARRRRRR }\end{array}$ & $\beta$-galactosidase & $\mathrm{HeLA}, \mathrm{Balb} / \mathrm{c}$ & $\begin{array}{l}\text { Proof of } \\
\text { transduction }\end{array}$ & [46][47] \\
\hline R7: RRRRRRR & $\begin{array}{l}\text { GFP, Estrogen } \\
\text { related receptor }\end{array}$ & $\begin{array}{l}\text { Human mesenchymal } \\
\text { stromal cells }\end{array}$ & $\begin{array}{c}\text { Comparative } \\
\text { analyses with SLO }\end{array}$ & [48] \\
\hline $\begin{array}{l}\text { R11: } \\
\text { RRRRRRRRRRR }\end{array}$ & $\begin{array}{l}\text { Sox2, Oct4, } \\
\text { cMyc, Klf4 }\end{array}$ & $\begin{array}{l}\text { Mouse embryonic } \\
\text { fibroblast }\end{array}$ & $\begin{array}{c}\text { Stem cell } \\
\text { reprogrammation }\end{array}$ & [49] \\
\hline $\begin{array}{l}\text { Pep-1: } \\
\text { KETWWETWWTE } \\
\text { WSQPKKKRKV }\end{array}$ & $\begin{array}{l}\text { Zn-superoxide } \\
\text { dismutase }\end{array}$ & Rat & $\begin{array}{l}\text { Protection against } \\
\text { Ischemia Insult }\end{array}$ & [52][53] \\
\hline $\begin{array}{l}\text { Ant TD: } \\
\text { FIRQIKIWFQNRR } \\
\text { MKWKK }\end{array}$ & $\begin{array}{l}\text { Transbody anti } \\
\text { C-Myc }\end{array}$ & HCT-116, MRC-5 & $\begin{array}{l}\text { Proof of } \\
\text { transduction }\end{array}$ & [50] \\
\hline $\begin{array}{l}\text { Penetratin : } \\
\text { RQIKIWFQNRRM } \\
\text { KWKK }\end{array}$ & $\begin{array}{l}\text { Transbody } \\
\text { ScFv anti M1 of } \\
\text { influenza virus }\end{array}$ & $\begin{array}{l}\text { A/H5N1-infected MDCK } \\
\text { cell }\end{array}$ & $\begin{array}{l}\text { Proof of } \\
\text { transduction }\end{array}$ & [51] \\
\hline $\begin{array}{l}\text { Zebra TD: } \\
\text { IKRYKNRVASRK } \\
\text { CRAKFKQLLQ }\end{array}$ & $\begin{array}{l}\text { Sox2, Oct4, } \\
\text { Lin28, Nanog }\end{array}$ & $\begin{array}{l}\text { Human neonatal dermal } \\
\text { fibroblasts }\end{array}$ & $\begin{array}{c}\text { Stem cell } \\
\text { reprogrammation }\end{array}$ & [54] \\
\hline $\begin{array}{l}\text { HYREVAAAKSSE } \\
\text { NDRLRLLLKQ }\end{array}$ & elF3f & Cancer cell lines & Cancer & [39] \\
\hline $\begin{array}{l}\text { SP-140 TD: } \\
\text { KPKRKRRKKKGH } \\
\text { GWSR }\end{array}$ & GFP, peptides & Caski or HSC-T6 cells & $\begin{array}{l}\text { Proof of } \\
\text { transduction }\end{array}$ & [55] \\
\hline $\begin{array}{l}\text { TAT-HA } \\
\text { YGRKKRRQRRR- } \\
\text { YPYDVPDVA }\end{array}$ & Bcl-xL & $\begin{array}{l}\text { Primary neurons; Murine } \\
\text { model of ischemia }\end{array}$ & $\begin{array}{l}\text { Protection against } \\
\text { Ischemia brain } \\
\text { injury }\end{array}$ & [63] \\
\hline $\begin{array}{l}\text { YGRKKRRQRRR- } \\
\text { YPYDVPDVA }\end{array}$ & Ndi1, catalase & Rat model of ischemia & $\begin{array}{c}\text { Protection against } \\
\text { myocardial } \\
\text { Ischemia injury }\end{array}$ & [64] \\
\hline $\begin{array}{l}\text { Syncytin-TAT: } \\
\text { PFVIGAGVLGALG } \\
\text { TGIGGI- } \\
\text { YGRKKRRQRRR }\end{array}$ & $\begin{array}{c}\text { EGFP, } \\
\text { alkylguanine- } \\
\text { transferase, } \\
\beta \text {-galactosidase }\end{array}$ & $\begin{array}{l}\text { HeLa, A431, HepG2, } \\
\text { and SK-N-SH }\end{array}$ & $\begin{array}{l}\text { Proof of } \\
\text { transduction }\end{array}$ & [65] \\
\hline
\end{tabular}


To link to this article (1) Chiper, M.; Niederreither, K.; Zuber, G. Transduction Methods for Cytosolic Delivery of Proteins and Bioconjugates Into Living Cells. Adv. Healthcare Mater. 2018, 7, e1701040.

Doi : 10.1002/adhm.201701040 
To link to this article (1) Chiper, M.; Niederreither, K.; Zuber, G. Transduction Methods for Cytosolic Delivery of Proteins and Bioconjugates Into Living Cells. Adv. Healthcare Mater. 2018, 7, e1701040.

Doi : 10.1002/adhm.201701040

Table 2. Main features of some proteins used for measuring the transduction efficiency

\begin{tabular}{|c|c|c|c|c|}
\hline Name & $\begin{array}{l}\text { Molecular/ } \\
\text { reporter activity }\end{array}$ & Purpose & Specificity/Scoop of action & Reference \\
\hline $\begin{array}{l}\text { Green Fluorescent } \\
\text { Proteins (GFP) }\end{array}$ & $\begin{array}{l}\text { Fluorescent } \\
\text { protein }\end{array}$ & $\begin{array}{c}\text { Quantitation \& } \\
\text { subcellular localization }\end{array}$ & $\begin{array}{l}\text { - Imagery assay } \\
\text { - Stable exogenous protein }\end{array}$ & Most \\
\hline $\begin{array}{l}\beta \text {-galactosidase } \\
\quad(\beta \text {-gal })\end{array}$ & $\begin{array}{l}\text { Hydrolyses } \beta \text { - } \\
\text { galactosides } \\
\text { and X-gal }\end{array}$ & $\begin{array}{l}\text { Proof of qualitative } \\
\text { delivery by hydrolysis of } \\
\text { X-gal in blue stains }\end{array}$ & $\begin{array}{l}\text { - Enzymatic reaction is not specific to } \\
\text { cytosolic localization } \\
\text { - Senescent cells have } \beta \text {-gal activity }\end{array}$ & $\begin{array}{c}{[34][40][108]} \\
{[85][164]}\end{array}$ \\
\hline $\begin{array}{l}\text { Cre-recombinase } \\
\quad(\text { enzyme })\end{array}$ & $\begin{array}{l}\text { Expression of } \\
\text { reporter gene }\end{array}$ & $\begin{array}{l}\text { Proof of functional } \\
\text { nuclear delivery in vitro } \\
\text { \& in vivo }\end{array}$ & $\begin{array}{c}\text { - Non-lethal assay relies on Genetically- } \\
\text { modified Organisms (GMOs) } \\
\text { - Relation dose-response unknown }\end{array}$ & $\begin{array}{c}{[56][66][67]} \\
{[119]}\end{array}$ \\
\hline $\begin{array}{l}\text { Caspase } 3 \\
(\text { Casp-3) }\end{array}$ & Apoptosis & $\begin{array}{l}\text { Proof of functional } \\
\text { delivery }\end{array}$ & $\begin{array}{c}\text { - Enzyme is fragile } \\
\text { - Lethal assay } \\
\text { - Relation dose-response unknown }\end{array}$ & $\begin{array}{c}\text { [86] [124] [129] } \\
{[152][156][162]} \\
{[164][165]}\end{array}$ \\
\hline $\begin{array}{l}\text { Cytochrome C } \\
\text { (CytC) }\end{array}$ & $\begin{array}{l}\text { Apoptosis when } \\
\text { in the cytosol }\end{array}$ & $\begin{array}{l}\text { Proof of qualitative } \\
\text { functional delivery }\end{array}$ & $\begin{array}{l}\text { - Endogenous mitochondrial protein } \\
\quad \text { - Lethal assay } \\
\text { - Relation dose-response unknown }\end{array}$ & [67] [107] \\
\hline $\begin{array}{l}\text { Saporin } \\
\text { (enzyme) }\end{array}$ & $\begin{array}{l}\text { Cell death by } \\
\text { inactivating } \\
\text { ribosomes }\end{array}$ & $\begin{array}{l}\text { Proof of qualitative } \\
\text { functional in vivo } \\
\text { delivery }\end{array}$ & $\begin{array}{c}\text { - Stable enzyme } \\
\text { - Lethal assay } \\
\text { - Relation dose-response unknown }\end{array}$ & [158] [116] [158] \\
\hline RNAse A & Cell death & $\begin{array}{l}\text { Proof of qualitative } \\
\text { functional delivery }\end{array}$ & $\begin{array}{c}\text { - Stable enzyme } \\
\text { - Lethal assay } \\
\text { - Relation dose-response unknown }\end{array}$ & [34] \\
\hline Granzyme B & Cell death & $\begin{array}{l}\text { Proof of qualitative } \\
\text { functional in vivo } \\
\text { delivery }\end{array}$ & $\begin{array}{l}\text { - Extracellular enzyme may be active } \\
\text { - Lethal assay } \\
\text { - Relation dose-response unknown }\end{array}$ & [135] \\
\hline $\begin{array}{l}\text { Sox2, Oct4, } \\
\text { cMyc, }^{\text {d) }} \text { KIf4 }\end{array}$ & $\begin{array}{c}\text { Morphology } \\
\text { differentiation }\end{array}$ & $\begin{array}{l}\text { Proof of delivery, cell } \\
\text { reprogrammation }\end{array}$ & $\begin{array}{l}\text { - Non-lethal assay } \\
\text { - Relation dose-response unknown }\end{array}$ & [67] [102] \\
\hline $\begin{array}{l}\text { Mouse Antibodies } \\
150 \mathrm{kDa} \text { IgG }\end{array}$ & $\begin{array}{l}\text { Blocking anti } \\
\text { HPV E6 }\end{array}$ & $\begin{array}{l}\text { Proof of functional } \\
\text { delivery in CaSki }\end{array}$ & $\begin{array}{l}\text { - Non-lethal assay } \\
\text { - Monoclonal antibody }\end{array}$ & [96] [96] [106] \\
\hline Antibodies & $\begin{array}{l}\text { Blocking anti- } \\
\quad \text { EG5 }\end{array}$ & $\begin{array}{l}\text { Proof of functional } \\
\text { delivery }\end{array}$ & $\begin{array}{l}\text { - Lethal assay with phenotype } \\
\text { - 24,000 molecules/cell } \\
\text { - Polyclonal antibody }\end{array}$ & [106] \\
\hline $50 \mathrm{kDa} F a b$ & $\begin{array}{l}\text { Blocking anti- } \\
\text { DNA } \\
\text { polymerase } \alpha\end{array}$ & $\begin{array}{l}\text { Proof of functional } \\
\text { delivery }\end{array}$ & $\begin{array}{c}\text { - Lethal assay with phenotype } \\
\left.-42,000 \text { molecules/cell }{ }^{9}\right) \\
\text { - } 50 \mathrm{kDa} \text { freely pass the nuclear pores }\end{array}$ & [19] \\
\hline $50 \mathrm{kDa} F a b$ & $\begin{array}{l}\text { Blocking anti- } \\
\text { PCNA }\end{array}$ & $\begin{array}{l}\text { Proof of functional } \\
\text { delivery }\end{array}$ & $\begin{array}{l}\text { - 600,000 PCNA molecules/HeLa cell } \\
\text { or } 40,000 \text { PCNA molecules/cell }\end{array}$ & [19] \\
\hline $\begin{array}{l}\text { Camelid } 16 \mathrm{kDa} \\
\text { Nanobodies }\end{array}$ & Anti-GFP & $\begin{array}{l}\text { Proof of functional } \\
\text { delivery }\end{array}$ & $\begin{array}{l}\text { - Non-lethal assay } \\
\text { - Library of GFP-fused proteins }\end{array}$ & {$[128]$} \\
\hline
\end{tabular}

a) GFP and derivatives such as enhanced GFP or nuclear-accumulated GFP; ${ }^{\text {b) }}$ from Kurz et al. ${ }^{[166]}$; c) from ${ }^{[167] ~ d)} 33000 \mathrm{cMyc}$ molecules/IMR90 cell ${ }^{[172]}$, e) HPV: Human Papilloma Virus-16; ${ }^{\text {f }}$ Caski are HPV-16 transformed cells; ${ }^{\text {g) }}$ from Schanhausser et

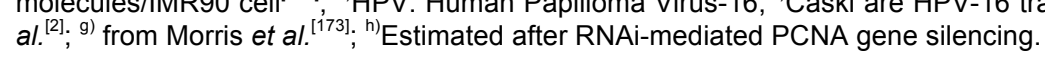






Manuela Chiper is currently Assistant Professor at Faculty of Pharmacy Strasbourg and performs research at the Research Institute of Biotechnology School (IREBS), University of Strasbourg, France. She received her $\mathrm{PhD}$ in 2008 at the Eindhoven University of Technology (the Netherlands) and performed postdoctoral trainings at the Université Catholique de Louvain-Belgium, Faculty of Pharmacy Tours, and the Faculty of PharmacyParis XI-France. Her research focuses on biocompatible nanosystems for therapeutic, diagnostic and imaging applications.

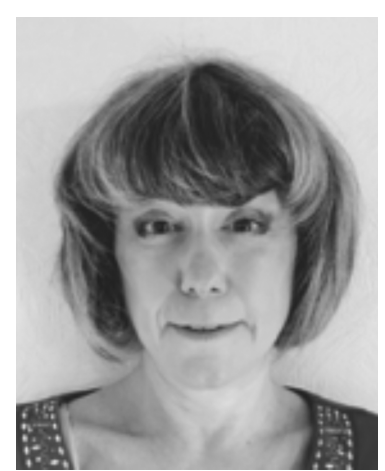

Karen Niederreither is currently an Associate Professor performing research at the Institut de Génétique et de Biologie Moléculaire et Cellulaire (IGBMC) and teaching at the University of Strasbourg Dental School (Faculté de Chirurgie Dentaire). Her laboratory at Baylor College of Medicine in Houston examined mechanisms through which retinoic acid signaling controls in utero development and stem cell dynamics. Upon relocating to Strasbourg France, her current research focuses on rare diseases, craniofacial patterning, and molecular targets of vitamin A signaling.



Guy Zuber is a Research Director at the "Centre National de la Recherche Scientifique (CNRS)" and he is currently in the Research Institute of the Biotechnology School at the University of Strasbourg, France. His main research interests are in the design, synthesis and 
biological evaluation of "synthetic virus-like" particles to convey macromolecules, such as proteins and synthetic nucleic acids into the cytosol of mammalian cells. Nanocarriers find applications in biomedical research and development and have medicinal potentials.

\title{
Direct delivery of recombinant proteins into the cytosol represents an alternative to
} genetic intervention. Cytosolic-active proteins heavily rely on assistance to pass across the plasma membrane. Here, various methods and approaches enabling cytosolic protein delivery are reviewed, along with their scope of action.

cytosolic delivery, protein carriers, intracellular delivery, protein transport, transduction

\section{Transduction Methods for Cytosolic Delivery of Proteins and Bioconjugates into Living Cells}

\author{
Manuela Chiper ${ }^{\mathrm{a}, \mathrm{b}}$, Karen Niederreither ${ }^{\mathrm{c}}$, Guy Zuber ${ }^{\mathrm{a} *}$
}

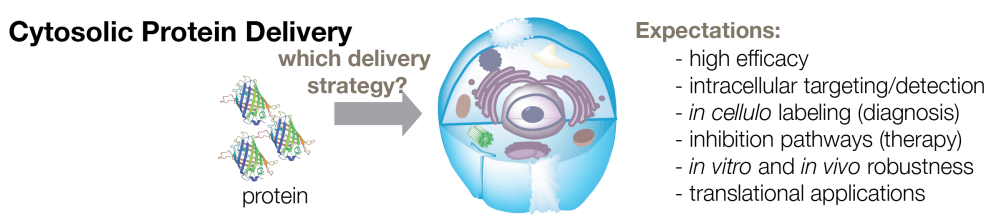

